\title{
Operationalizing ecosystem-based adaptation: harnessing ecosystem services to buffer communities against climate change
}

\author{
Christine Wamsler $^{1,2}, \underline{\text { Lisa Niven }}^{1}, \underline{\text { Thomas H. Beery }}^{3}, \underline{\text { Torleif Bramryd }}^{4}, \underline{\text { Nils Ekelund }}^{5}, \underline{K}_{\text {. Ingemar Jönsson }}{ }^{6}, \underline{\text { Adelina Osmani }}^{1}$, \\ Thomas Palo $^{7}$ and Sanna Stålhammar ${ }^{1}$
}

\begin{abstract}
Ecosystem-based approaches for climate change adaptation are promoted at international, national, and local levels by both scholars and practitioners. However, local planning practices that support these approaches are scattered, and measures are neither systematically implemented nor comprehensively reviewed. Against this background, this paper advances the operationalization of ecosystem-based adaptation by improving our knowledge of how ecosystem-based approaches can be considered in local planning (operational governance level). We review current research on ecosystem services in urban areas and examine four Swedish coastal municipalities to identify the key characteristics of both implemented and planned measures that support ecosystem-based adaptation. The results show that many of the measures that have been implemented focus on biodiversity rather than climate change adaptation, which is an important factor in only around half of all measures. Furthermore, existing measures are limited in their focus regarding the ecological structures and the ecosystem services they support, and the hazards and risk factors they address. We conclude that a more comprehensive approach to sustainable ecosystem-based adaptation planning and its systematic mainstreaming is required. Our framework for the analysis of ecosystem-based adaptation measures proved to be useful in identifying how ecosystem-related matters are addressed in current practice and strategic planning, and in providing knowledge on how ecosystem-based adaptation can further be considered in urban planning practice. Such a systematic analysis framework can reveal the ecological structures, related ecosystem services, and risk-reducing approaches that are missing and why. This informs the discussion about why specific measures are not considered and provides pathways for alternate measures/designs, related operations, and policy processes at different scales that can foster sustainable adaptation and transformation in municipal governance and planning.
\end{abstract}

Key Words: climate change adaptation; ecosystem management; ecosystem services; green infrastructure; municipal planning; naturebased solutions; renaturing cities; risk reduction; spatial planning; sustainability transitions; urban planning; urban resilience; urban transformation

\section{INTRODUCTION}

Climate change poses a serious challenge to sustainable urban development and places cities at increasing risk (IPCC 2014). In the absence of adequate international responses to address its impacts and given the need for place-based solutions, local authorities have a pivotal role in advancing comprehensive climate change adaptation (Roberts 2008, Roberts et al. 2011, Rauken et al. 2015).

Increasingly, ecosystem-based approaches to climate change adaptation have been put forward at international, national, and local levels, and have attracted interest from scholars and practitioners alike (e.g. Andersson 2006, World Bank 2009, Roberts et al. 2011, UNFCCC 2011, Huq et al. 2013, Wilkinson et al. 2013, Chong 2014, IPCC 2014, Wu 2014). Ecosystem-based adaptation is a relatively new concept that can be defined as the "use of biodiversity and ecosystem services as part of an overall adaptation strategy" (CBD 2009:41). It aims to harness the services of ecosystems to buffer communities against the adverse effects of climate change, including climate extremes and variability (Gill et al. 2007, Foster et al. 2011, Gaffin et al. 2012, Jones et al. 2012, Munang et al. 2013). The Fifth Assessment Report of the United Nations Intergovernmental Panel on Climate Change (IPCC 2014) and the recent Sendai Framework for Disaster Risk Reduction 2015-2030 $0^{[1]}$ (UNISDR 2015) recognize for the first time that ecosystem management is an important way to reduce urban risk and build resilience, which requires further investigation (CBD 2009, IPCC 2014, UNISDR 2015).

While there is growing interest in ecosystem-based adaptation, local planning practice that supports appropriate actions is scattered and inconsistent, and there is lack of both systematic implementation and comprehensive reviews of measures (Doswald et al. 2014, IPCC 2014). Furthermore, empirical analysis of the integration of ecosystem services in local planning is limited (Turnpenny et al. 2014).

Against this background, this paper advances the operationalization of ecosystem-based adaptation by improving our knowledge of how ecosystem-based approaches have, and can be, considered in urban planning practice. The focus is thus on the operational governance level. We scrutinize current research on ecosystem services in urban areas and examine four coastal municipalities in Sweden to identify the key characteristics of implemented and planned ecosystem-based adaptation measures. Based on the results, we discuss the core issues that can help to ensure their effective and meaningful application.

Sweden was selected as the geographical focus of the empirical analysis because it is a declared forerunner and pioneer in both environmental and climate-change planning and tops the Global

${ }^{1}$ Lund University Centre for Sustainability Studies (LUCSUS), ${ }^{2}$ Centre for Societal Resilience, ${ }^{3}$ Kristianstad University, ${ }^{4}$ Environmental Strategy, Lund University Campus Helsingborg, ${ }^{5}$ Malmö University, ${ }^{6}$ School of Education and Environment, Kristianstad University, ${ }^{7}$ Department of Wildlife, Fish and Environmental Studies, Swedish University of Agricultural Sciences (SLU) 
Green Economy Index (Jordan and Lenschow 2000, Hertin and Berkhout 2001, Lenschow 2002, Granberg and Elander 2007, Dual Citizen 2014, Persson et al. 2015). In addition, Sweden is of particular interest because it expects substantial climate change impacts (SOU 2007, Länsstyrelserna 2012) and because ecosystem-based approaches have been consistently promoted by the government of Sweden since 2007 (SOU 2007, 2013, Ministry of the Environment 2013). Notably, the Swedish Commission on Climate and Vulnerability acknowledged the important role of ecosystems and their components in climate change adaptation, stating that "access to biodiversity and robust ecosystems is an important resource for handling and surviving climate-related crises" (SOU 2007:397). In 2013, the government produced a report called Making the Value of Ecosystem Services Visible, which set the goal of ensuring that by 2018 "the importance of biodiversity and the value of ecosystem services are to be generally known and integrated into economic positions, political considerations and other [planning] decisions in society" (Ministry of the Environment 2013:3). In this context, Sweden's southern region (Scania County) has made particular progress (Länsstyrelsen i Skåne län 2014) ${ }^{[2]}$ and is thus the focus of this study (Fig. 1).

Fig. 1. Case study areas in Scania County, Southern Sweden.

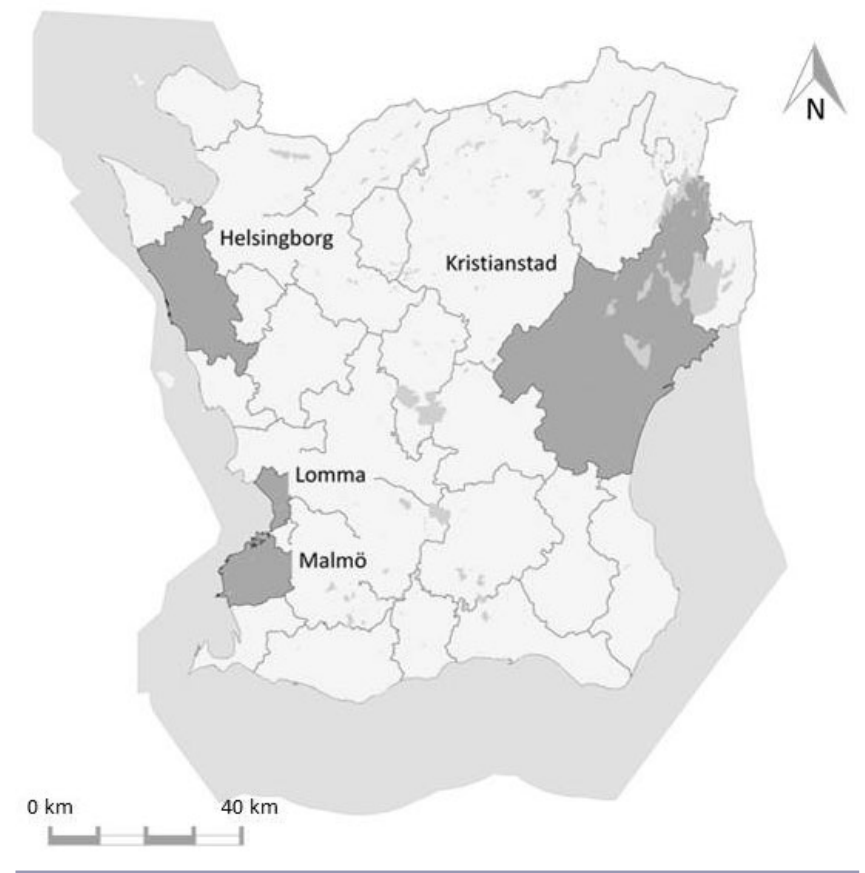

\section{METHODOLOGY}

In a first step, a multiple case study approach (Yin 2009) was applied, which looked at the Swedish coastal cities of Malmö, Helsingborg, Kristianstad, and Lomma located in Scania County (Fig. 1). The municipalities were selected using purposive sampling (Glaser and Strauss 1967, Tongco 2007), based on their risk exposure, high environmental profile, and proactive approach to climate risk-related research and projects. The selected municipalities have, for instance, been proactive in the regional research circles Planning Under Increased Uncertainty and Ecosystem Services Planning, and in two major research projects financed by the Swedish Environmental Protection Agency and the Swedish Research Council FORMAS. A "municipal planning monopoly" exists. In fact, the principle of self-governance has a long tradition in Sweden, and municipalities have a pivotal role in urban planning and service provisioning, while national legislation provides related guidance (SALAR [date unknown]; cf., Nadin and Stead 2008, Reimer et al. 2014). ${ }^{[3]}$

The analysis was guided by the following research questions: Does local planning include ecosystem-based adaptation (explicit and implicit)? If yes, how are ecosystem services included in implemented and planned on-the-ground measures ${ }^{[4]}$ Based on the answers to these questions, the key characteristics of identified measures were discussed, together with the core issues necessary to ensure their application.

Data were collected during 2014-2015 using a literature review and face-to-face interviews, focus group discussions with key informants, and a survey including staff from municipal departments engaged in spatial or environmental planning. Proactive civil servants have been identified as key actors in adaptation mainstreaming (Roberts 2010); therefore, the focus group, survey participants, and the interviewees were selected through purposive sampling based on their field of activity within the municipality and participation in adaptation and ecosystemrelated activities. Thirteen in-depth interviews with key informants lasting between two and three hours were carried out and transcribed. The interview protocol was based on the analytical framework presented in the following section. The survey included 20 municipal staff members and 4 policy makers, and the focus group discussions included a total of 18 participants. Both the survey and the focus group discussions were designed to follow up on the preliminary outcomes and triangulate the data obtained from the interviews with key informants and the context-specific literature review. This initial literature review provided information about the selected cities and their activities (e.g., project descriptions, municipal reports) and included an in-depth analysis of the cities' strategic adaptation plans. ${ }^{[5]}$ The latter aimed to identify potential future developments and compare municipalities' strategic adaptation goals with local practice. The identification of relevant adaptation plans/strategies was based on interviews. The analysis of other strategic planning documents was outside the scope of this study.

Qualitative and quantitative data analyses were used. For the qualitative data analysis, a combination of literal reading, grounded theory (Glaser and Strauss 1967, Strauss and Corbin 1998), and systems theory (von Bertalanffy 1950, Bateson 1979, Hördur 2004) was applied. ${ }^{[6]}$ The identification and analysis of relevant passages consisted of five stages: (1) coding scheme development consistent with the analytical framework, (2) identification of potentially relevant texts, (3) application of the coding scheme, (4) identification of patterns through qualitative and quantitative analyses, and (5) discussion of preliminary findings with key informants and municipality staff, and inclusion of their feedback. The latter was carried out via email communication and the above-mentioned focus group discussions. For example, the draft paper presenting the research 
findings was circulated to key informants in the assessed municipalities to assure the accuracy of the findings and stimulate further discussion.

In a second step, the results of the empirical work on the four case study areas were compared with a review of current research on ecosystem services in Swedish urban planning. The search strings used were "ecosystem service" AND "Sweden" AND "urban." Using the Scopus database, we retrieved a total of 26 articles. This approach made it possible to compare current practice, strategic planning, and research, and finally open up a discussion of wider issues with international relevance, including the barriers and drivers related to mainstreaming ecosystem-based adaptation into municipal planning and governance.

\section{ANALYTICAL FRAMEWORK}

The analytical framework is based on the concepts of ecosystem services, climate change adaptation, and disaster risk reduction. The use of the ecosystem services concept has expanded rapidly in recent years (Hubacek and Kronenberg 2013). Ecosystem services are described as "the conditions and processes through which natural ecosystems, and the species that make them up, sustain and fulfill human life" (Daily 1997:3). They can be classified into four broad categories: (1) supporting services such as water cycling and biodiversity; (2) provisioning services such as the supply of food, fuel, and fiber; (3) regulating services such as water purification and the regulation of local and global climate; and (4) cultural services such as social relations and good health (Millennium Ecosystem Assessment 2005, Haines-Young and Potschin 2013).

Climate change adaptation is described by the Intergovernmental Panel on Climate Change as "adjustment in natural or human systems in response to actual or expected climatic stimuli or their effects, which moderates harm or exploits beneficial opportunities" (IPCC 2007:27), which can be a conscious, i.e., explicit, or unconscious, i.e., implicit, response (IPCC 2014). Adaptation actions are often divided into so-called hard and soft approaches, with the former focusing on engineered structures and the latter on issues such as awareness raising and institutional capacity building (Jones et al. 2012). So-called green, or ecosystem-based, adaptation measures can be considered either as a third way (Naumann et al. 2011, Jones et al. 2012) or as part of a more widely framed soft approach (Kithiia and Lyth 2011, Sovacool 2011).

In ecosystem-based adaptation approaches, ${ }^{[7]}$ ecological structures, ${ }^{[8]}$ their functions, and the services they provide are used to increase the capacity of areas and their inhabitants to reduce risk caused by climatic extremes and variability. They also have cobenefits; i.e., they help to meet multiple environmental, social, and economic objectives (CBD 2009, Naumann et al. 2011). Adaptation-relevant services of ecological structures such as vegetation, forests, grasslands, wetlands, and water bodies mainly include regulating services, such as local climate, natural hazards, and water and soil regulation (Bolund and Hunhammar 1999, Niemelä et al. 2010). Other adaptation-relevant services can include, but are not limited to, food and fiber provisioning, pest control and disease regulation, and preservation of genetic diversity (see, e.g., UNFCCC 2012). Ecosystem-based adaptation planning is thus a specific dimension of ecosystem management, an overarching strategy to handle the complexity of environmental challenges, which has been developed in research and practice since the 1990s (Borgström et al. 2015). Ecosystem management is an approach "that integrates ecological, socio-economic, and institutional factors into comprehensive analysis and action in order to sustain and enhance the quality of ecosystems to meet current and future needs," including climate risk and related vulnerability (UNEP 2011:13). ${ }^{\text {[?] }}$

The implementation of an ecosystem-based adaptation approach involves different types of on-the-ground activities, such as the creation, conservation, restoration, and management of ecosystems provided by green and blue infrastructure ${ }^{[10]}$ (Colls et al. 2009, IPCC 2014). Activities thus involve a wide range of ecosystem management activities that consist of a variety of bluegreen infrastructure components, such as parks and gardens, trees in streets, permeable surfaces, green roofs, and urban wetlands, watercourses, ponds, and lakes that are explicitly or implicitly aimed at reducing climate risk.

Ecosystem-based approaches are discussed in the fields of both climate change adaptation and disaster risk reduction (Doswald and Estrella 2015). Adaptation and risk reduction concepts largely overlap (Thomalla et al. 2006, EU 2013, IPCC 2014, Wamsler 2014, Doswald and Estrella 2015). Both are cross-cutting, i.e., mainstreaming, issues and require systematic integration into municipal operations and decision making to achieve sustainable transformation (IPCC 2012, Wamsler 2014). In the urban planning context, both concepts address climate-related risks in a defined geographical area based on a cyclical process that involves (1) assessing current risk, (2) reviewing current risk-reducing practice, (3) assessing potential measures, (4) prioritizing and implementing certain measures, and (5) evaluating and managing them (Füssel 2007, Moser and Ekstrom 2010, IPCC 2012, Länsstyrelserna 2012).

Hence, ecosystem-based adaptation measures can be classified according to their risk-reducing approach to (1) hazard reduction to keep climate hazards outside communities; (2) vulnerability reduction to allow communities to live with climate hazards; and (3-4) preparedness for response or recovery to cope with climate hazard impacts. The term "hazard" relates to both climatic extremes and variability. All four of these risk-reducing approaches can be implemented either as separate activities/projects that are explicitly aimed at reducing risk or can be mainstreamed into the core work of departments along with other primary goals (Wamsler 2014). Accordingly, in our study, measures that have climate risk reduction both as an intended, i.e., explicit, or unintended aim or cobenefit are termed ecosystem-based adaptation measures.

This conceptual understanding translates into four analytical steps for assessing and systematizing ecosystem-based adaptation approaches. ${ }^{[11]}$ First, measures can be analyzed in terms of the types of activities and their primary aims. Second, they can be examined in terms of ecological structures, i.e., structures that are conserved, restored, or created for ecosystem-based adaptation. Third, they can be assessed according to which of the four riskreducing approaches they contribute to through the services they generate. Fourth, their cobenefits can be investigated. These analytical steps formed the basis for the coding scheme described in the previous section. ${ }^{[12]}$ 


\section{RESULTS}

In accordance with the research questions and the analytical framework, all measures were analyzed in terms of (1) the aim and type of activity, (2) the ecological structure(s) used, (3) their risk-reducing approach, and (4) their cobenefits. These aspects are described and discussed in relation to current approaches in research in the following subsections. An analysis of implemented, on-the-ground measures is followed by an analysis of planned measures.

\section{Ecosystem-based adaptation in local practice}

\section{Aim and type of implemented measures}

Overall, measures mentioned during interviews and in the survey were almost equally divided between externally funded, limitedduration projects and measures that are integrated into and are part of the ongoing core work of the municipality. The most common primary aim $(32 \%)$, as well as the most frequently mentioned secondary aim, is biodiversity increase or preservation (Fig. 2, cf., Fig. 7). This is followed by improved storm water management $(29 \%)$, recreation $(12 \%)$, and increasing or ending the loss of green space $(9 \%)$. Climate change adaptation $(6 \%)$ is in fifth place, together with the reduction of eutrophication (e.g., through wetland creation and restoration) and improved water quality. In addition, climate change adaptation is mentioned as a secondary reason for the implementation of only half of all other measures. Surprisingly, climate change mitigation is the primary aim of only $3 \%$ of ecosystem-based measures. The prevention of riverine or coastal floods and coastal erosion, implemented unrelated to climate change and adaptation, also is featured (3\%; Fig. 2).

Fig. 2. Primary aims of identified ecosystem-based adaptation measures.

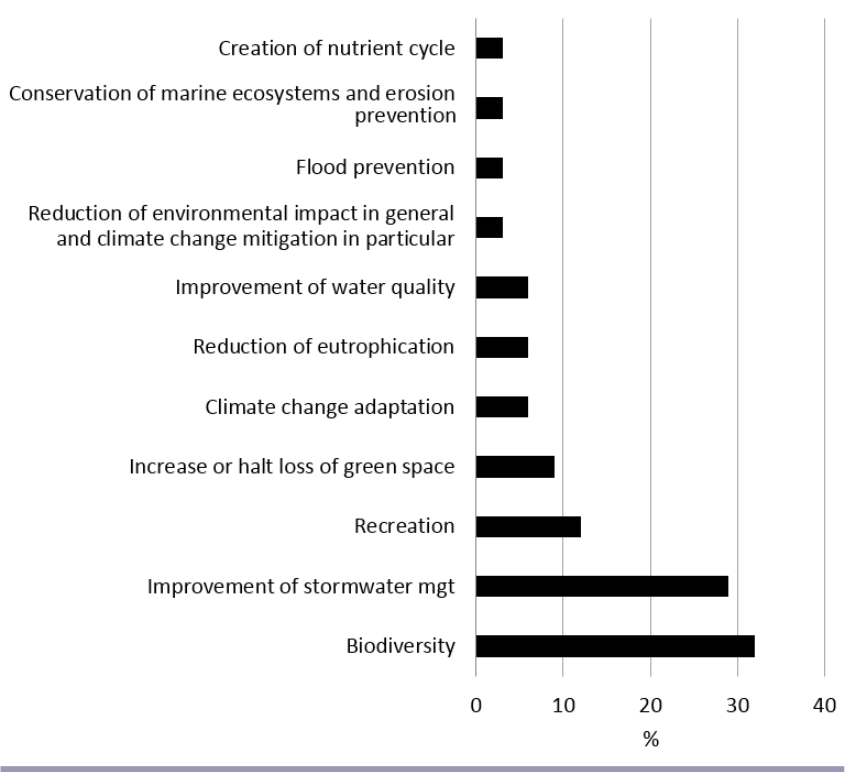

The most frequently mentioned types of measures were an increase in urban vegetation and its quality, e.g., through improved biodiversity, in streets and other public or private areas $(26 \%)$, followed by green roofs and facades (21\%), and the implementation of ecological water management systems (18\%). The latter includes the installation of open water channels, water retention areas, the reduction of runoff, and incentives for users to alter their practices through disconnecting downspouts and installing ecological water features. Other, far less frequent $(9 \%$ or $6 \%$ ) measures are the renaturalization of rivers, wetlands, and other landscapes; the improvement of coastal management through the management of mussel banks and the preservation of underwater eel grass meadows; the creation or maintenance of nature reserves; the increase of urban vegetation through mobile plant systems; and the protection of agricultural land by prohibiting construction (Fig. 3).

\section{Ecological structures}

Ecological structures used included mainly trees and other plant coverage, such as green roofs, walls, and street furniture $(68 \%$ in relation to implemented measures; Fig. 4). Wetlands, rivers, ponds, and ditches followed ( $42 \%$ combined), which reflects the increasing importance given to ecological storm water management and renaturalization processes.

Contribution to adaptation: risk-reducing approach

Increased precipitation and flood risk were the most frequently addressed hazards $(56 \%$ combined, in relation to hazards addressed in implemented measures; Fig. 5). In many cases, precipitation and flooding are causes and effects of essentially the same hazard. Heatwaves are in second place $(25 \%)$, followed by rising sea levels and erosion (14\% combined). However, several measures can be termed multihazard because they address different hazards at the same time, which seems to have encouraged their use. For example, green roofs can both lower flood risk and reduce heat via evapotranspiration.

In terms of risk-reducing approaches (cf., Analytical Framework), most measures contribute to vulnerability reduction ( $91 \%$ in relation to implemented measures; Fig. 6). Hazard reduction is less frequent $(24 \%)$ and relates mainly to the prevention of coastal floods and erosion (e.g., through the preservation of eel grass meadows) and maintaining water bodies in and around cities (e.g., through the renaturalization of wetlands, the creation of nature reserves, and the prohibition of construction on agricultural land). Response and recovery preparedness were neither considered nor mentioned.

Contributions to risk assessment that inform risk-reducing approaches only related to environmental compensation measures, where climate-related impacts are also considered, and adaptation-focused projects, which generally include such assessments in the project design. Interviewees mentioned sophisticated analyses of certain types of risk in particular areas: for example, the MIKE modeling tool in Helsingborg and Kristianstad that predicts flood risk (see MIKE Powered by DHI, http://www.mikepoweredbydhi.com/). In Kristianstad, a large, collaborative project called Resilience Increasing Strategies for Coasts Toolkit (RISC-KIT) has recently started. The project is funded by the European Union (EU) and involves 10 countries; it aims to develop methods for and management approaches to risk reduction linked to hydro-meteorological events in coastal zones. It addresses all aspects of the risk reduction framework, from risk assessment, including assessment of ecosystem services, to response and recovery preparedness. 
Fig. 3. Types of ecosystem-based adaptation measures identified.

Pilot projects, national demonstration areas of climate adapations (and upscaling of local experiences)

Planning for a different urban forestry, for instance less spruce

Prevention plans for green areas to reduce climate change and/or human-made impacts on ecosystem services (e.g. forest fire as a result of human behavior or tree loss as a result of heat, drought, new diseases and insect infestations)

Support of urban blue infrastructure (including increase in fountains and creation of green-blue corridors)

rotection of agricultural land

Increase of urban vegetation through mobile plant systems and three-dimensional greenery

Creation or maintenance of nature reserves

Coastal management (management of mussel banks, preservation of underwater eel grass meadows)

Re-naturalization of rivers, wetlands (creation and restoration) and other landscapes

Ecological stormwater management (including open water channels, water retention, reduction of water run-off, incentives for water users to alter their practices through disconnecting downspouts and installing ecological water features)

Increase of urban vegetation through green roofs and facades

Increase or maintenance of urban vegetation and its quality along streets, public green areas, and private areas (including compensation for impact on/loss of ecological structures)

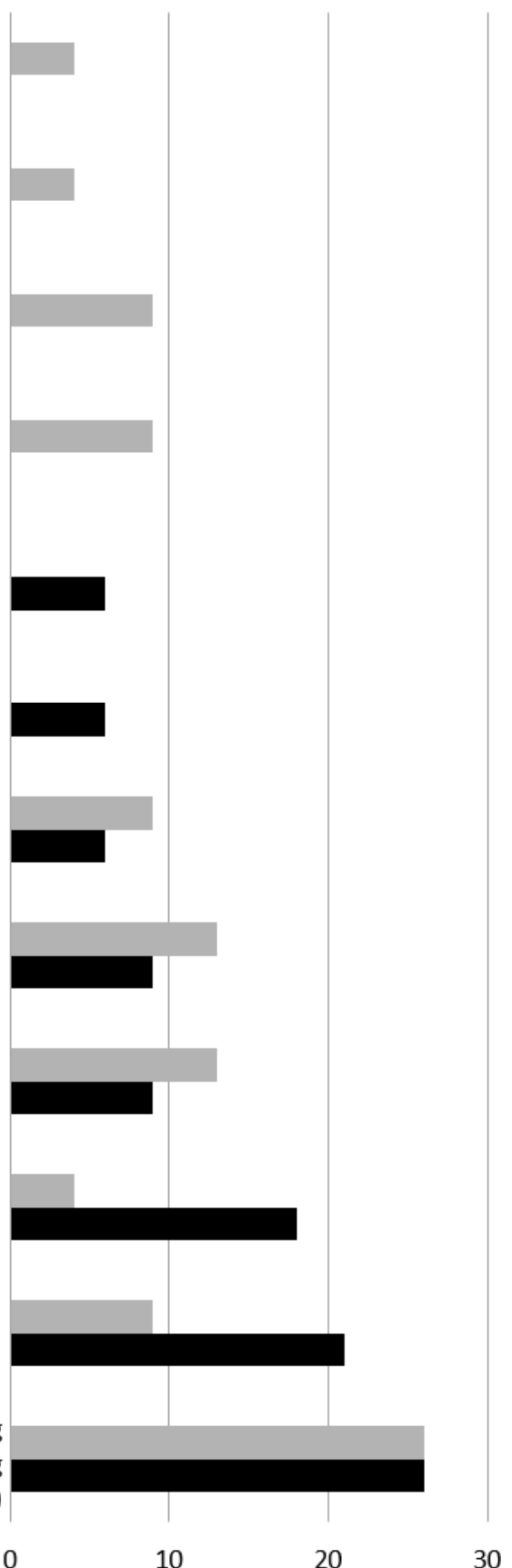

$\%$ in relation to planned measures

$\%$ in relation to implemented measures

\section{Cobenefits}

Of the measures that have climate change adaptation as their primary or secondary aim, the most frequently mentioned cobenefits were habitat creation and biodiversity $(25 \%)$, public health $(21 \%)$, aesthetics $(14 \%)$, recreation $(11 \%)$, and carbon sequestration, air quality, and economic considerations ( $8 \%$; Fig. 7 , percentage in relation to cobenefits of implemented measures with adaptation being the primary aim or coreason). Economic considerations related to lower costs in comparison with grey infrastructure (e.g., for water management), increased land value, or higher revenue from ecotourism. Other cobenefits included pollination (4\%), education and knowledge (3\%), water purification $(3 \%)$, waste treatment $(1 \%)$, and nutrition cycling $(1 \%)$. 
Fig. 4. Ecological structures used in identified measures. Multiple categorizations of single measures are included.

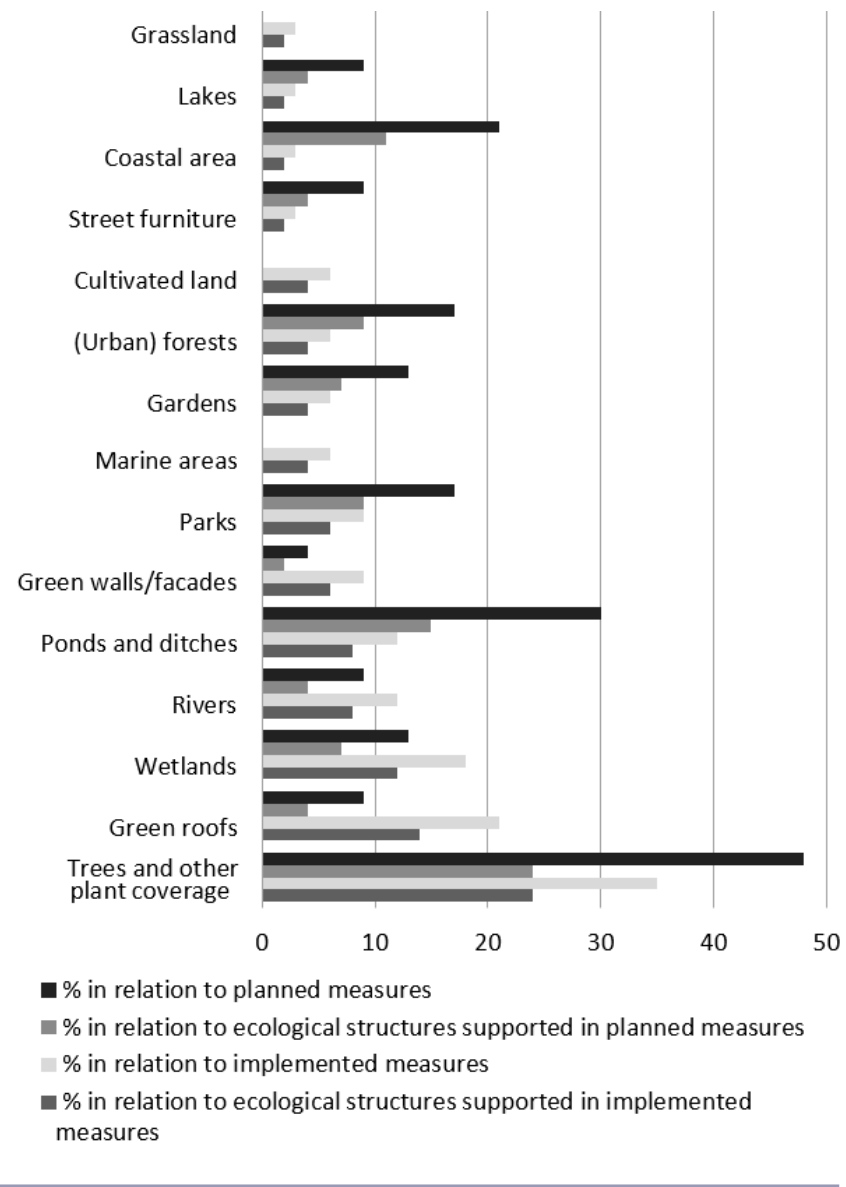

Fig. 5. Hazards addressed by identified measures. Multiple categorizations of single measures are included.

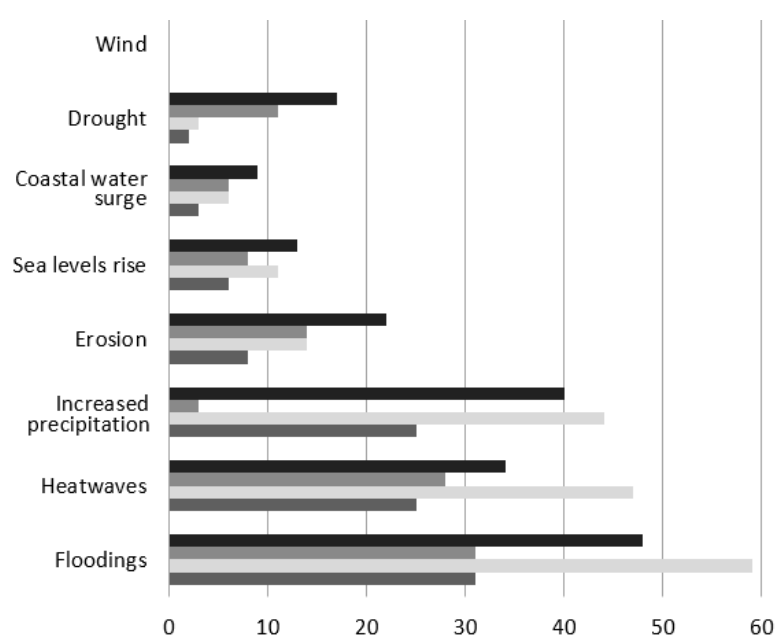

- $\%$ in relation to planned measures

a $\%$ in relation to hazards addressed in planned measures

$\%$ in relation to implemented measures

a in relation to hazards addressed in implemented measures
Fig. 6. Risk-reducing approach of identified measures. Multiple categorizations of single measures are included.

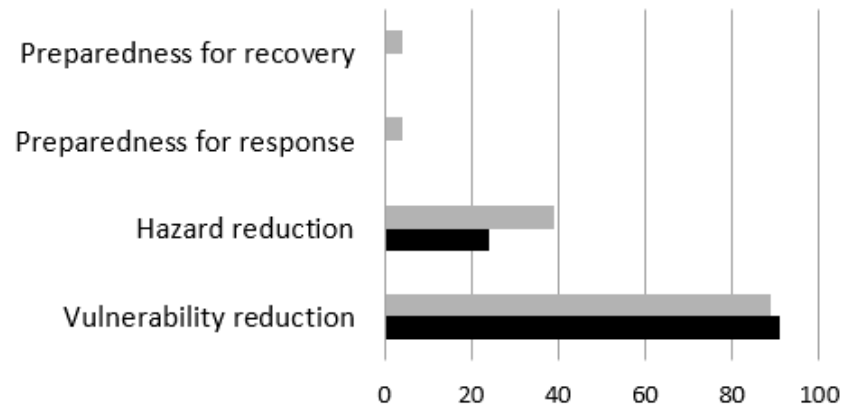

\% in relation to planned measures

[ $\%$ in relation to implemented measures

Fig. 7. Cobenefits of identified measures. Multiple categorizations of single measures are included.

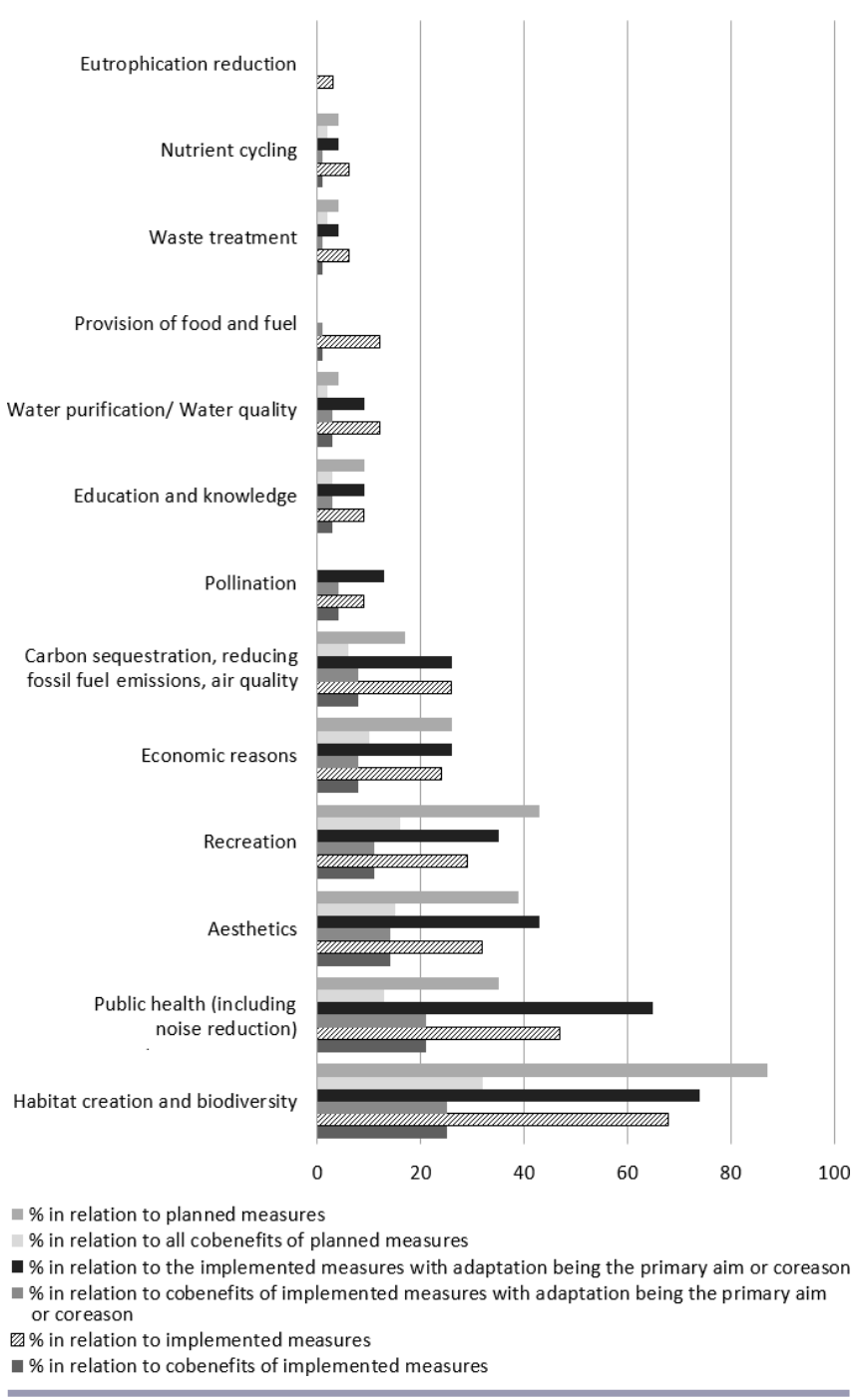


Cross-case analysis and data triangulation

Floods are the primary risk addressed by ecosystem-based adaptation measures. This is based on past events and a belief that the risk of flooding is easier to communicate than other hazards. Consequently, flood prevention and management through improved storm water management were the second most frequently mentioned primary aim, after biodiversity, reflecting the long history of the topic in Sweden, and especially in Malmö. Recreation was the third primary aim, confirming the importance given to the socio-cultural services of ecosystems. Although sea level rise and windstorms are other important hazards, they received little attention. Wind was only mentioned in relation to what types of measures should be avoided, i.e., vegetation that is unable to withstand wind or can harm neighboring buildings, resulting in high expenses for its removal. In addition, wind was considered in risk analyses for coastal flooding, e.g., in Kristianstad and Helsingborg.

All interviews confirmed a slow shift from technological hazard mitigation to more nature- and risk-based adaptation planning, which is in line with developments promoted at the EU level, such as the 2007 Floods Directive (e.g., EU 2007). At the same time, municipalities take slightly different approaches to the use of ecosystem-based adaptation measures. Malmö is notable for the high percentage of project-based measures and external funding. Consequently, measures are most varied, especially green infrastructure components. The municipality has a long tradition of open stormwater management, and individual champions and flagship projects have increased knowledge about its advantages for climate change adaptation. The 2007 and 2014 floods were frequently noted as the starting point for incremental improvements.

Kristianstad is a uniquely vulnerable location. Parts of the municipality are up to 2.4 meters below sea level (Sweden's lowest point). Consequently, there are many technical (hard) flood protection measures in place that address past and current risk rather than future climate impacts. However, the Helge River, on which Kristianstad is situated, is predicted to have a $20 \%$ increase in the risk of a 100-year flooding event (EU 2009, SMHI 2011), leading to the assessment of alternative approaches.

Kristianstad and Lomma are most focused on coastal areas and coastal planning processes, and intermunicipal and international collaboration is given great weight in this context to address risk and related measures that go beyond the municipalities' administrative borders. Kristianstad's management of its Biosphere Reserves (the Kristianstad Vattenrike, established in 2005) has been widely acknowledged. In Lomma there is a longstanding interest in collaboration on river and watershed management, which incorporates changing climatic conditions. Helsingborg focuses on its waterfront and technical solutions to protect the so-called "H+" area, an urban regeneration project. It is also notable for its historical and ongoing use of wetlands, its recognition of climate impacts on commercial and recreational forest areas, and urban-rural links in terms of ecosystem services provision and consumption.

In addition to the on-the-ground measures outlined in the previous section, interviewees mentioned recent changes and processes that are relevant to ecosystem-based adaptation, but that have not yet resulted in concrete outcomes. They cited externally financed initiatives that aim to improve the assessment of ecosystem services provision, gather relevant information, foster knowledge-sharing processes, and develop methods and tools for planning and assessment. Although these processes have yet to bear fruit, they are likely to support future ecosystem-based adaptation.

In all municipalities, coastal planning processes are under way that have long-term implications for adaptation and the way the coastal area is managed. These processes are influenced by the EU Marine Strategy Framework Directive (2008/56/EC, incorporated into Swedish law in 2010) and more importantly, the EU Framework for Maritime Spatial Planning (2014/89/EU, to be incorporated into Swedish law by 2016). The latter requires municipalities to produce coastal plans that integrate an ecosystem-based approach. This is expected to lead to more soft and green measures, unlike the hard measures that dominate in current adaptation strategies.

A comparison of the empirical data with the literature on ecosystems services in Swedish urban contexts shows that there is little academic discussion of ecosystem-based adaptation. Climate change adaptation is mentioned in only four papers, and only indirectly. If it is mentioned at all, adaptation is included only as a secondary issue, when discussing regulating ecosystem services (Larondelle et al. 2014) or as a general challenge, in terms of "how to manage social-ecological systems ... in a way that does not erode their adaptive capacity and ability to cope with environmental changes" (Elmqvist et al. 2004, Borgström et al. 2006:2). Schewenius et al. (2014) presents a project called URBES, which although it claims to guide local adaptation, does not explicitly address the issue.

Furthermore, the literature focuses on the management of urban green areas (cf., Fig. 3), especially around Stockholm (e.g., Elmqvist et al. 2004, Barthel et al. 2005, 2010, Hougner et al. 2005, Colding et al. 2006, Ernstson et al. 2008, Andersson et al. 2014, Schwenius et al. 2014). Like the empirical data, the literature does not pay much attention to blue versus green areas in cites. Brink et al. (2016) identify the same focus at international level. Only a few authors look in detail at water (e.g., Jansson and Nohrstedt 2001, Jansson and Colding 2007, Larondelle et al. 2014, Queiroz et al. 2015), and no direct link is made with urban adaptation. A reason for this might be the fact that related measures (e.g., watershed management) often go beyond administrative borders and, thus, municipalities' decision powers (cf., Länsstyrelsen Skåne 2014, SOU 2014).

Although the international literature increasingly highlights the importance of not only considering regulating ecosystem services for adaptation (e.g., Lavorel et al. 2015), this is not reflected in practice. Another prominent theme is the importance of social movements for ecosystem-based adaptation. In this context, "increasingly ... attention has turned toward how groups in civil society and their respective management practices influence the spatial arrangements and quality of urban ecosystems" (Ernstson et al. 2008:1). This is linked to the idea of diversifying the actors involved in the governance of areas that provide ecosystem services.

Finally, consistent with the identified aims and cobenefits (Figs. 2 and 7), research into ecosystems services in Swedish urban 
contexts confirms that biodiversity, health issues, and recreation take priority. Andersson et al. (2014) and Querioz et al. (2015) show that biodiversity and cultural services (e.g., recreation and health issues) have a high profile in urban municipalities, and note that cultural services provide the most common link between urban green spaces and human well-being.

\section{Ecosystem-based adaptation in strategic adaptation planning}

Strategic planning documents for climate change adaptation in the four case study areas were analyzed to identify strategic planning measures. These documents are the following:

1. The Promemoria Climate Adaptation 2012 of Helsingborg, published by the city planning and technical services department (Helsingborgs stad 2012).

2. The Climate Strategy, Goals and Action Plan 2011 of Kristianstad, published by C4 Technical administration (Kristianstads kommun 2011).

3. The Dialogue Memorandum 2008 of Malmö: climate, sea level, and planning, published by the city planning office (Malmö stad 2008).

4. The Action Plan for Climate Change 2012-14 of Malmö, published by the environmental department (Malmö stad 2011, 2012).

5. The Action Plan for Climate Change of Lomma, from the planning department and the municipal management office. $^{[13]}$

With the exception of the Malmö Dialogue Memorandum 2008, all of these documents describe measures that fall within the definition of ecosystem-based adaptation presented here. The term "ecosystem services" appears three times in the Malmö Action Plan, in the context of better storm water management, increased biodiversity, recreation, microclimate, and other ecosystem services. It does not appear in the other documents. Other key terms such as "green space" and "biodiversity" and key ecological structure terms such as "forest" and "wetland" appear, however, in the context of described measures that contribute to an ecosystem-based adaptation approach. Nevertheless, the lack of specific information in strategic adaptation plans meant that not all aspects of the analytical framework could be analyzed in detail. Instead, the analysis focused on identifying additional information and/or discrepancies between the content of interviews and the survey, and potential future developments.

\section{Aim and type of planned measures}

Ecosystem-based measures mentioned in the strategic adaptation documents aim to reduce climate risk. Most, but not all, measures are intended to be part of the municipality's core work. Exceptions are pilot projects and demonstration areas, such as the Risebergabäcken project in Malmö.

The types of ecosystem-based adaptation measures mentioned are shown in Figure 3 (percentages in relation to planned measures). The most frequently mentioned measures are the increase or maintenance of urban vegetation and its quality in public and private areas (26\%), where new models, approaches, and forms of cooperation are planned. They include models for construction and refurbishment that reward greenery, in addition to more distributed climate governance and collaboration through, for instance, providing advice to property owners
(Malmö stad 2012). A further measure is to improve the quality of urban vegetation through the creation of blue-green corridors (e.g., Helsingborgs stad 2012). New measures that did not emerge in interviews or the survey are coastal management through beach nourishment in Helsingborg and Kristianstad (cf., Kristianstads kommun 2011, Helsingborgs stad 2012); planning for more resilient urban forestry, e.g., reduced spruce planting; and greater support for urban blue infrastructure, e.g., fountains. Furthermore, these documents include measures that aim to reduce negative effects on ecosystem services caused by both changing climate patterns and inadequate human behavior. Examples include prevention plans for green areas to avoid tree loss due to heat, drought, new diseases, and insect infections (Helsingborgs stad 2012); information campaigns; and new routines to reduce climate-related risks in outdoor recreation areas, e.g., prevention of forest fires caused by humans (Helsingborgs stad 2012).

\section{Ecological structures}

The planned measures cover a wide range of ecological structures (Fig. 4). Trees and vegetation (the most generic category), combined with parks, forests, and gardens, make up half of the structures mentioned ( $49 \%$ in relation to ecological structures supported in planned measures). Planned support for new forms of city-citizen collaboration concerning private land and for blue infrastructure can also be seen to some extent (Fig. 5). Private gardens are more strongly represented, together with ponds, ditches, lakes, and coastal areas.

\section{Contribution to adaptation: risk-reducing approach}

Ecosystem-based measures put almost equal emphasis on higher temperatures and floods (ca. $31 \%$ each in relation to hazards addressed in planned measures; Fig. 5), followed by erosion $(14 \%)$. Wind was only mentioned in the context of risk and risk assessments for sea level rise and erosion, but not in relation to specific ecosystem-based measures.

The identified measures contributed most frequently to vulnerability reduction $(89 \%)$, followed by hazard reduction $(39 \%$ in relation to planned measures; Fig. 6). There are signs of increased awareness of preparedness measures to improve hazard response and recovery (together, 8\%) through information campaigns, working routines, and management plans for green areas (Helsingborgs stad 2012). Risk assessment is linked to improvements in detailed planning and management plans that take climate change into consideration (Kristianstads kommun 2011, Helsingborgs stad 2012). It is also mentioned in the context of adaptation-focused projects (Malmö stad 2011).

\section{Cobenefits}

Many cobenefits were identified in relation to measures outlined in strategic planning documents (Fig. 7, in relation to all cobenefits of planned measures). Those most mentioned were habitat creation and biodiversity $(32 \%)$, recreation $(16 \%)$, aesthetics $(15 \%)$, health $(13 \%)$, and economic considerations $(10 \%)$. An example of the latter is increased capacity for the forestry industry and sustainable profits (Kristianstads kommun 2009, 2011).

\section{Cross-case analysis and data triangulation}

There are both similarities and differences in strategic planning documents with respect to their scope, level of detail, and relevance to ongoing work. A frequent criticism of municipalities 
is that they incorporate too many hard structures (Länsstyrelsen Skåne 2014, Andersson et al. 2015), and this is reflected in the fact that more than $80 \%$ of planned adaptation measures fall into this category. Nevertheless, a considerable number of ecosystembased measures can also be identified, especially in the Malmö and Helsingborg plans and to a certain extent, Kristianstad. Measures are very variable in terms of their specificity, and are often mentioned in a nonsystematic and speculative way, making direct comparisons difficult. However, general patterns in current and future planning practice can be identified and are presented in the Discussion.

The literature on ecosystem services in Swedish urban areas provides additional information on the relevance of strategic planning documents for ecosystem-based adaptation in this context. Wilkinson et al. (2013) compare planning documents over more than 70 years and conclude that "at least for the field of strategic spatial planning, an ecosystem services approach per se does not bring novel insights with respect to the framing of human-nature relations" (Wilkinson et al. 2013:11). The paper does conclude, however, that "even in its most basic form the ecosystem services concept is a useful tool to expose the specific way in which ecosystem related matters are addressed in strategic planning." Our study indicates that this might also be true for the ecosystem-based adaptation concept.

The ecosystem services literature further gives increasing prominence to the role of nonmunicipal actors in managing informal urban green spaces (Colding 2006, Andersson et al. 2007, Ernstson et al. 2008). Although some of the strategic adaptation documents reflect this, related measures are very limited in both number and scope.

\section{DISCUSSION}

The results from the Swedish context make it possible to identify the key characteristics of ecosystem-based adaptation measures, compare current operationalization with strategic planning approaches, discuss the core issues necessary to ensure their effective and meaningful application, and relate them to other places, contexts, and research.

\section{Key characteristics of ecosystem-based adaptation measures}

Consistent with research from other contexts (e.g., Tompkins et al. 2010), this study shows that adaptation measures are rarely undertaken solely in response to climate change. Of the identified measures that have already been implemented, most have other primary goals. Biodiversity through the increase in the quantity and quality of green areas is a key focus, which features in all municipalities and in the literature. Biodiversity also appears as the most common cobenefit in strategic plans. Because biodiversity is an inherent component of the ecosystem service and the ecosystem-based adaptation concept, it can generally be seen as both a unifying and a driving force for ecosystem-based adaptation. It contributes to greater adaptive capacity and resilience through, for instance, genetic diversity and redundancy (Elmqvist et al. 2003). The link between diversity and climate change adaptation is, however, more obvious in applications such as agriculture and agroforestry than in the urban context, and by itself it is clearly insufficient to systematically address climate risk via this approach. Hence, climate risk has not yet been addressed comprehensively with respect to hazards and risk factors, and the related ecological structures and services to mitigate these factors.
In addition, carbon sequestration and climate change mitigation were in the Swedish case studies only weakly linked to ecosystembased adaptation. This is despite a growing international debate on the importance of combining mitigation and adaptation efforts for addressing sustainability in cities (e.g., Davoudi 2009, Davoudi et al. 2009, Munang et al. 2013, EC 2015), unlike other countries where climate change mitigation is driving the adaptation agenda of municipalities (Wamsler 2015).

Furthermore, this study shows that a few standard approaches to ecosystem-based adaptation seem to dominate, similar to other contexts (e.g., Doswald and Osti 2011). These include green roofs, ecological stormwater management, and the renaturalization of landscapes to increase buffer capacity, generally implemented by the municipalities themselves. Other, more innovative approaches that involve a greater variety of stakeholders are rare. Nevertheless, consistent with other research and planning contexts, a slight move toward more participatory approaches can be observed (cf., Davies et al. 2015, Hansen et al. 2015).

\section{Synergies and differences between local practice and planning}

The comparison of local practice, i.e., the operationalization of ecosystem-based adaptation, and future planning indicates a move toward more comprehensive adaptation planning. This is demonstrated in several ways. First, the focus on green infrastructure is being replaced by greater interest in combined blue-green infrastructure approaches. Second, a broader approach is being taken to the types of measures that are promoted. Third, a more balanced approach is being taken to address existing hazards, and response and recovery preparedness is receiving more attention. Fourth, there also seems to be increasing interest in involving citizens and other actors. Finally, there is a trend toward a more comprehensive consideration of ecosystem services-adaptation links that include (1) the use of ecosystem services for adaptation; (2) the impact of climate change on ecosystem services and related adaptation; and (3) the impact of human behavior on ecosystem services, resultant risk, and related adaptation. Such a comprehensive approach is crucial to achieve sustainable transformation (cf., UNFCCC 2011, IPCC 2012, 2014, Wamsler 2014).

Despite these positive developments, in practice climate change adaptation planning is still in its infancy, and there is little evidence of explicit action. Moreover, ecosystem-based adaptation approaches lag even further behind. Compared with hard engineering measures, the proportion of green measures included in the strategic adaptation plans varies from none (Malmö stad 2008 ) to around $20 \%$ (Helsingborgs stad 2012). In addition, the extent to which planned measures have been initiated or will be implemented in the future is difficult to assess. In Helsingborg, interviewees mentioned that although departments generally attempt to follow the plan, it is not always successful. A working group was therefore established in December 2013 to ensure improved follow-up in the future. In Malmö, the climate adaptation plan was created by the Environment Department as a deliverable for the EU-funded project Green and Blue Space Adaptation for Urban Areas and Eco Towns (GRaBS), which explains its focus on green and blue issues. However, municipal staff reported that the project ended in 2011 and that the plan "was never formally used." Interviewees agreed that "At the planning stage a lot of things can be activated, but when it comes 
to concrete implementation it often looks very differently." Similar challenges have been identified in other contexts (e.g., Sitas et al. 2014).

Another common theme in practice and strategic planning is the lack of integration between adaptation and risk reduction, both in Sweden and in other contexts. While the need is recognized in theory (e.g., Uy and Shaw 2012, IPCC 2014, Wamsler 2014), there are many barriers at the municipal level such as separate financing schemes, departmental responsibilities, and regulations (cf., Wamsler 2014). Consequently, many risk reduction initiatives and related ecosystem-based measures are carried out separately from adaptation-related efforts in terms of staff, mechanisms, and processes.

Finally, in both local practice and strategic planning, the focus is on regulating services in relation to climate change adaptation, whereas theory indicates that it is crucial also to include other services. Provisioning and livelihood aspects of ecosystem-based adaptation can, for instance, contribute to vulnerability reduction and response and recovery preparedness (Dixon et al. 2009, Gupta and Nair 2012, Uy et al. 2012). Furthermore, social networks and community bonds can buffer the impacts of extreme events (Pelling 1998, Nakagawa and Shaw 2004, Ernstson et al. 2008). In this context, the contribution of blue and green spaces to social cohesion and network formation (e.g., through identity creation and the provision of space for community activities) has not yet been considered. This would contribute to a more comprehensive understanding of vulnerability reduction and would link such measures to response and recovery preparedness. No such links could, however, be identified in the empirical data.

\section{Mainstreaming ecosystem-based adaptation: driving forces and barriers}

Our results provide evidence that systematic mainstreaming at the institutional and interinstitutional levels is an indispensable precondition for achieving sustainable implementation of on-theground measures. This study was limited to local-level operations, i.e., the operational governance level, and did not focus on mainstreaming strategies at institutional and interinstitutional levels. The latter was the subject of a separate study (see Wamsler et al. 2014). Nevertheless, some general drivers of and barriers to adaptation mainstreaming could be identified. These include financial and human resources, knowledge and information, leadership, and formal responsibilities that have also been identified in other contexts (cf., Moser and Ekstrom 2010, Uittenbroek et al. 2013, Doswald et al. 2014, Wamsler 2014). In addition, aspects specific to ecosystem-based approaches could be identified. These drivers and barriers are presented in Table 1 .

The two conceptual components of ecosystem-based adaptation, i.e., ecosystem services and climate change adaptation, are socalled cross-cutting or mainstreaming issues (Vignola et al. 2009, Wamsler 2014). Therefore, they must be integrated into existing operations, planning, and decision-making mechanisms at municipal level, rather than being seen as extra considerations to be added on and weighed against others (cf., Holden 2004, Wamsler et al. 2013).

However, roughly half of the implemented ecosystem-based adaptation measures were undertaken in the context of externally funded projects that did not form part of the department's core work. Staff characterized their work on adaptation in general, and ecosystem-based adaptation in particular, as highly dependent on project funding, which reflects the lack or unclear division of responsibilities, factors that have also been identified in other research (e.g., Storbjörk 2007). Although externally funded projects can generate interest in, and raise the profile of, ecosystem-based adaptation, related activities must be integrated into a comprehensive mainstreaming approach; otherwise, it becomes difficult to achieve sustainable transformation when the funding runs out (demonstrated by Malmö's action plan for climate change adaptation). Nonetheless, some current core activities were originally developed as part of a flagship project. An example is the adoption of the "green space factor" in building programs in Malmö, originally developed for the Västra Hamnen (Bo01) project.

Furthermore, the study identified a slight development toward more distributed governance of adaptation, especially in externally funded projects. This is important in promoting intrainstitutional mainstreaming (cf., Table 1, Wamsler 2014). Many of the projects that were, or are, promoting ecosystembased adaptation are funded at the EU and/or national level, and are undertaken in collaboration with nongovernmental actors, which contributes to greater diversity in the governance regime. This could be seen as evidence of an experimental or more distributed approach to climate governance, which changes the traditional dynamics of urban authority. This development has, to date, principally been identified in the context of climate change mitigation (Bulkeley and Betsill 2003, Bulkeley 2013).

The development toward more distributed adaptation governance was also seen in strategic planning documents. This is especially important in the context of ecosystem-based adaptation, because more distributed governance of ecosystem services is expected to lead to more diverse planning approaches that allow corresponding with different scales of ecosystem service generation. Scale mismatches were identified as being particularly common in the heterogeneous urban environment (Borgström et al. 2006). Therefore, it is essential to understand the scale of operation of ecosystem services in urban planning (e.g., sectoral and resource management plans) for ecosystem-based adaptation to become sustainable (Jansson and Colding 2007). Furthermore, timescale mismatches related to a lack of ongoing attention given to ecosystem services in strategic plans can have negative implications for sustainable service generation (Wilkinson et al. 2013). The contribution and transfer of knowledge between individuals and groups of actors involved in managing particular areas are thus important in bridging scales and mediating between levels of governance (cf., Andersson et al. 2007).

More distributed governance also reflects increased city-citizen collaboration, which is required for effective mainstreaming and sustainable transformation (Stott and Huq 2014, Wamsler 2014). Although several interviewees noted that adaptation planning lacks citizen engagement, some initial progress could be identified (cf., the previous two sections of the Discussion). In Malmö, the water company offers economic incentives to consumers who disconnect their downspouts and divert water onto their lawn or into water features to help stormwater management. Informing residents about how they can increase the green qualities of their garden and the contribution this makes to climate change 
Table 1. Institutional and interinstitutional driving forces and barriers to the mainstreaming of ecosystem-based adaptation measures that were identified by interviewees.

\begin{tabular}{|c|c|c|}
\hline Levels of mainstreaming & Barriers & Drivers \\
\hline $\begin{array}{l}\text { Institutional level } \\
\text { Managerial and } \\
\text { working structures } \\
\text { (internal formal } \\
\text { and informal } \\
\text { norms and job } \\
\text { descriptions as } \\
\text { well as the } \\
\text { configuration of } \\
\text { sections or } \\
\text { departments) }\end{array}$ & $\begin{array}{l}\text { Funding: EbA has multiple benefits that can } \\
\text { lead to unclear financial responsibilities for their } \\
\text { implementation and maintenance, hampering } \\
\text { taking related action. } \\
\text { Departmental structures and power relations: } \\
\text { "This is such hard work when you have to } \\
\text { communicate between all departments related to } \\
\text { the issue [of ecosystem-based adaptation] ... It is } \\
\text { a power game." } \\
\text { Staff responsibilities and capacities: Difficulties } \\
\text { working with planners who may lack scientific } \\
\text { knowledge relevant to EbA. }\end{array}$ & $\begin{array}{l}\text { Funding: EbA can be cheaper than engineering solutions and } \\
\text { provide multiple benefits. } \\
\text { Departmental structures and power relations: Regular } \\
\text { restructuring after elections, which can be a positive way to } \\
\text { initiate sustainability transformations (although this opportunity } \\
\text { is often missed). } \\
\text { Departmental structures and power relations: EbA calls into } \\
\text { question the separation between conservation and construction- } \\
\text { based planning. } \\
\text { Staff responsibilities and capacities: Existing staff member(s) } \\
\text { responsible for mainstreaming EbA and related operational } \\
\text { purposes. } \\
\text { Staff responsibilities and capacities: Individual champions who } \\
\text { push local solutions. "We had a wonderful person here [at Malmö } \\
\text { municipality] who lies behind all the good things that we've been } \\
\text { doing in waste- and stormwater management...." } \\
\text { EbA can be cheaper than engineering solutions and provide } \\
\text { multiple benefits. }\end{array}$ \\
\hline $\begin{array}{l}\text { Planning } \\
\text { procedures and } \\
\text { related activities } \\
\text { (formal and } \\
\text { informal plans, } \\
\text { regulations, } \\
\text { policies, and } \\
\text { legislations) }\end{array}$ & $\begin{array}{l}\text { National regulations: In the field of climate } \\
\text { change adaptation guidance is very limited. } \\
\text { Local regulations: Lack of legal support for } \\
\text { incorporation of green roofs and green space } \\
\text { factors into building requirements. } \\
\text { "Unfortunately the [national] government } \\
\text { doesn't ... want the municipalities to have their } \\
\text { own requirements beside the Planning and } \\
\text { Building Act, so even though we have been using } \\
\text { this [green space factor] for a couple of years } \\
\text { now, I'm not really sure whether we're allowed to } \\
\text { do this." } \\
\text { Local regulations: No legal basis for designing } \\
\text { green facades for adaptation purposes, only } \\
\text { aesthetic justifications are valid. } \\
\text { Local regulations: Lack of legal guarantees that } \\
\text { green areas used for adaptation purposes will } \\
\text { not be built on, difficulty in incorporating into } \\
\text { detailed planning. } \\
\text { Planning procedures and funding: "Ecosystem- } \\
\text { based adaptation goes against traditional } \\
\text { planning... You get a lot of money for things } \\
\text { related to aesthetic things but not for } \\
\text { sustainability issues." } \\
\text { Competing interests: Open stormwater } \\
\text { management and increase in green spaces } \\
\text { compete with other aims such as densification. }\end{array}$ & $\begin{array}{l}\text { National regulations: Support of ecosystem services by national } \\
\text { government (e.g., Ministry of the Environment, 2013). } \\
\text { National regulations: In contrast to climate change adaptation, in } \\
\text { environmental planning (which falls under the national } \\
\text { environmental quality objectives) municipalities are provided } \\
\text { with clearer and more defined local measures. } \\
\text { Local regulations: "In order to create a change it needs to be } \\
\text { legally binding.... There need to be stronger requirements in the } \\
\text { comprehensive plans. But we can see that things are slowly } \\
\text { changing." }\end{array}$ \\
\hline
\end{tabular}


Interinstitutional level

Collaboration between individual sections or departments and other stakeholders (departments, committees, organizations, governmental bodies, and citizens)
Administrative borders and related funding:

Current intermunicipal water utility ownership means that projects that benefit only one municipality are unlikely to be funded.

Citizen involvement: Mechanisms not available for private housing owners to save money for future renovations without paying significant taxes, which hampers incorporating EbA measures in existing areas.

Citizen involvement: The preference of residents of the municipalities for paved areas over gardens or green areas with higher infiltration capacity.

Competing interests: In the past, individuals could block (with media support) progress in EbA (e.g., creation of a nature reserve).

All levels (i.e., local, institutional, and interinstitutional)

Political support Lack of political will for climate change and direction (to adaptation.

support education and change at the other mainstreaming levels)
Competing interests: "Politicians want to satisfy the will of the people, and build things... A politician can understand what is important but they won't act because of the electors, ... people want them to do something else."
Funding: Some measures, such as green roofs have become "cheap to implement for developers."

Funding: Cost sharing for open stormwater management between public and private actors.

Citizen involvement: Citizens could positively influence municipal work on EbA through related local and political engagement.

Science-policy integration: Collaboration with research institutes, such as the Scandinavian Green Roof Institute, leads to

improvement of technical knowledge.

Decision making: EbA requires cross-border measures (e.g., watershed and wetland management), which can be both a driver for and a barrier to taking action.

Political popularity: Political actors are seen as critical to the process. Ecosystem services have high political popularity. "If anything is cool in the political world, it's ecosystem services."

Supportive politicians who enable planners with ecological knowledge to take initiatives.

EbA indicates ecosystem-based adaptation.

adaptation is one of the actions cited in Malmö's Climate Change Action Plan (Malmö stad 2012). Linking with networks of citizens in coastal areas and processes such as coastal councils are frequently mentioned, and they are seen as useful ways to exchange information and encourage interactions with municipal employees on an eye-to-eye level, rather than on a citizen-tobureaucratic-institution level. At the same time, there is an emphasis on the need for further dialogue with local residents.

In practice, current levels of city-citizen involvement fall short of the goal of "citizen science" considered by some scholars to be necessary for transdisciplinary problem solving (Dickinson et al. 2012). Existing efforts are useful starting points for bringing citizens into the processes, but they need to progress from participation (e.g., in the form of information) to empowerment (Arnstein 1969) and collaborative planning approaches. Such approaches are key principles of ecosystem-based adaptation (UNFCCC 2012) and its mainstreaming in municipal planning and governance (Wamsler et al. 2014). Once mainstreamed, coordination and implementation should become part of the routine, rather than the result of a deliberate mobilization and struggle (cf., Healey 1997).

\section{CONCLUSIONS}

Ecosystem-based adaptation is gaining in prominence at international, national, and local levels. It is therefore necessary to develop a solid understanding of the ways in which the conceptual foundations (ecosystem services and climate change adaptation) can be adequately combined and operationalized. In an urban planning context, this requires (1) an understanding of the links between ecosystems, their structures, and the adaptationrelevant services they provide for reducing climate risk; and (2) communication of these services to decision makers from different backgrounds who are involved in strategic and on-theground operations.

In accordance with Sweden being a declared forerunner and pioneer in both environmental and climate-change planning, ecosystem-based approaches are to some extent already integrated into strategic adaptation planning. However because of the sporadic nature of the implementation of these plans, and the lack of clear responsibilities for adaptation, the implementation of planned measures is limited.

At the operational level, there is a range of different measures, from experimental, project-based applications to well-established techniques, e.g., in stormwater management, although they mainly address historical risk. In this context, blue infrastructure components receive less attention than vegetation. In addition, many of the measures that have been implemented do not have climate change adaptation as their primary aim. Biodiversity, improved stormwater management, and recreation are key goals in all municipalities. Surprisingly, climate change mitigation is generally neither a primary goal nor a cobenefit. While the diversity of aims and cobenefits is encouraging, multiple benefits are not systematically examined and prioritized in relation to specific measures. In addition, because adaptation is often not a primary aim, the measures are limited in their risk-reducing 
approach. Although ecosystem-based adaptation measures can address both current and future climate risk, their contribution also seems to be undervalued by those responsible for risk reduction, and there is little evidence of the systematic application of risk-reducing approaches to ecosystem-based adaptation. Furthermore, the value of ecosystem services for transforming to a state that supports social adaptation is not considered. However, a slight increase in more distributed governance of adaptation and ecosystem services could be identified. Further integration of nongovernmental stakeholders and existing social networks could advance mainstreaming and make the benefits and cobenefits of ecosystem-based adaptation measures more explicit. This would contribute to the debate on the nature of adaptation, i.e., what needs to be adapted and the extent to which traditional versus ecosystem-based measures are (or should be) implemented.

The analytical framework presented here has proven to be useful in identifying the core characteristics, patterns, trends, and weaknesses in the operationalization of ecosystem-based approaches and in providing knowledge on how ecosystem-based adaptation can further be considered in urban planning practice. It is a systematic analysis framework, which can reveal how ecosystem-related measures are addressed in current practice and strategic adaptation planning, highlighting the ecological structures, related ecosystem services, and the risk-reducing approaches that are (or are not) taken into account. This enables, in turn, a more informed discussion about what is missing and alternatives (i.e., ecosystem-based measures/designs and related governance operations and policy processes at different scales) that could help to achieve urban transformation. Whether or not in this context temporary external support can lead to sustainable adaptation and transformation in urban planning and governance requires further research. In fact, further study is required of the dynamic relationships found between innovative practices launched in the context of flagship or experimental projects and their cross-cutting integration into day-to-day municipal work, related mainstreaming levels and strategies, ${ }^{[14]}$ and city-citizen collaborations.

${ }^{[1]}$ The Sendai Framework for Disaster Risk Reduction is the successor instrument to the Hyogo Framework 2005-2015 (UNISDR 2005).

${ }^{[2]}$ See also https://temfunderingar.wordpress.com/2011/03/23/ ekosystemtjanster-viktiga-for-skanes-grona-strategiarbete/

${ }^{[3]}$ For a comprehensive description of the Swedish planning system, see http://commin.org/upload/Sweden/SE_Planning_System in English.pdf

${ }^{\left[{ }^{[4]}\right.}$ The analysis of related institutional and/or regulatory structures was outside the scope of this research, and has been assessed in other studies (Länsstyrelsen Skåne 2014, SOU 2014, Wamsler et al. 2014).

${ }^{[5]}$ Related data were collected between February 2014 and February 2015. Later developments could not be included.

${ }^{[6]}$ Consistent with grounded theory, a combination of open coding, axial coding, and selective coding was applied to the empirical data (Glaser and Strauss 1980, Strauss and Corbin 1998). Based on the research setting and the analytical framework, some organizational categories were established prior to the review of interviews or documents. Glaser and Strauss acknowledged that it is possible to discover and work with prior/ tentative theoretical frameworks, which they also call substantive theory (as opposed to formal theory; Glaser and Strauss 1980, Layder 2005). The organizational categories functioned as primary "bins" for sorting the transcribed/written data for further analysis. Within the established categories, patterns were identified through a comparison of the different empirical data during the analysis process, which included literal reading. During axial coding, the commonly used linear paradigm model was expanded by a broader, nonlinear systems analysis approach. More information about the case studies-grounded theorysystems analysis approach can be found in Wamsler (2007).

${ }^{[7]}$ The term "ecosystem-based adaptation" became increasingly popular after 2008 through its support by international funding authorities (World Bank 2009, UNFCCC 2011).

${ }^{[8]}$ Ecological structures are defined as a collection of species, individuals, communities, functional groups, or habitats that deliver an ecosystem service (Liu et al. 2003, Kremen 2005, Luck et al. 2009).

${ }^{[9]}$ See the International Union for Conservation of Nature (http:// iucn.org/).

${ }^{[10]}$ This concept highlights the importance of the natural environment (i.e., vegetation and water bodies) in decisions about land use planning.

${ }^{[11]}$ Note that in accordance with the research focus the analytical framework relates to on-the-ground measures rather than related institutional/regulatory structures, which have been assessed in related studies (cf., Länsstyrelsen Skåne 2014, SOU 2014, Wamsler et al. 2014).

${ }^{[12]}$ The identification of subcategories in the coding scheme was either inductive (types of activities, primary aims, cobenefits, hazards) or deductive (risk-reducing approaches, ecological structures). The classification of ecological structures used was developed from the literature (e.g., Bolund and Hunhammar 1999, Niemelä et al. 2010). Some important components of green and blue infrastructure are not specifically mentioned in this classification but are considered as combinations of other categories. For example "bioswales" combines the "vegetation" and "ponds and ditches" categories (cf., Figures 2-7).

${ }^{[13]}$ This document had not been published at the time of this study. The information presented here is based on discussions held during its preparation. Furthermore, unlike other municipalities, the Action Plan for Climate Change of Lomma is an appendix to the municipality's comprehensive plan. The analysis of the comprehensive plan itself was outside the scope of this study and forms part of another research study by the authors (N. G. A. Ekelund, P. Schubert, A. Roth, T. Bramryd, K. I. Jönsson, C. Wamsler, T. H. Beery, S. Stålhammar, and T. R. Palo, unpublished manuscript).

${ }^{[14]}$ For a detailed description of mainstreaming levels and strategies, see Wamsler $(2014,2015)$. The framework presented here links to the local household level and related mainstreaming strategies, providing input on, but not addressing the means for, their institutionalization. Its focus is on the operational governance level (cf., Frantzeskaki and Tilie 2014).

Responses to this article can be read online at: http://www.ecologyandsociety.org/issues/responses. $\mathrm{php} / 8266$ 


\section{Acknowledgments:}

This research was carried out in the context of the Implementing the Ecosystem Services Concept at the Municipal Level (ECOSIMP) project financed by the Swedish Environmental Protection Agency (no. 13/143) and Region Skåne (Miljövårdsfonden M066/2013), as well as the Sustainable Urban Transformation for Climate Change Adaptation project financed by the Swedish Research Council FORMAS (no. 2011-901). We would like to thank all project partners for their contribution, namely, the municipalities of Kristianstad, Malmö, Lomma, Helsingborg, Trelleborg, Simrishamn, and Båstad; Scania's Association of Local Authorities; the universities of Kristianstad, Malmö, and Lund; and the Swedish University of Agricultural Sciences (SLU). Thanks also to Stephan Pauleit and the anonymous reviewers for their valuable input.

\section{LITERATURE CITED}

Andersson, E. 2006. Urban landscapes and sustainable cities. Ecology and Society 11(1):34. [online] URL: http://www. ecologyandsociety.org/vol11/iss1/art34/

Andersson, E., S. Barthel, and K. Ahrné. 2007. Measuring socialecological dynamics behind the generation of ecosystem services. Ecological Applications 17(5):1267-1278. http://dx.doi. org/10.1890/06-1116.1

Andersson, E., S. Barthel, S. Borgström, J. Colding, T. Elmqvist, C. Folke, and Å. Gren. 2014. Reconnecting cities to the biosphere: stewardship of green infrastructure and urban ecosystem services. Ambio 43:445-453. http://dx.doi.org/10.1007/s13280-014-0506-y

Andersson L., A. Bohman, L. van Well, A. Jonsson, G. Persson, and J. Farelius. 2015. Underlag till kontrollstation 2015 för anpassning till ett förändrat klimat. SMHI Klimatologi $\mathrm{Nr} 12$, SMHI, SE-601 76. SMHI, Norrköping, Sweden.

Arnstein, S. 1969. A ladder of citizen participation. Journal of the American Institute of Planners 35(4):216-224. http://dx.doi. org/10.1080/01944366908977225

Barthel, S., J. Colding, T. Elmqvist, and C. Folke. 2005. History and local management of a biodiversity-rich, urban cultural landscape. Ecology and Society 10(2):10. [online] URL: http:// www.ecologyandsociety.org/vol10/iss2/art10/

Barthel, S., C. Folke, and J. Colding. 2010. Social-ecological memory in urban gardens-retaining the capacity for management of ecosystem services. Global Environmental Change 20(2):255-265. http://dx.doi.org/10.1016/j.gloenvcha.2010.01.001

Bateson, G. 1979. Mind and nature: a necessary unity-advances in systems theory, complexity, and the human sciences. Hampton Press, New York, New York, USA.

Bolund, P., and S. Hunhammar. 1999. Ecosystem services in urban areas. Ecological Economics 29(2):293-301. http://dx.doi. org/10.1016/s0921-8009(99)00013-0

Borgström, S., Ö. Bodin, A. Sandström, and B. Crona. 2015. Developing an analytical framework for assessing progress toward ecosystem-based management. Ambio 44(suppl 3):357-369. http://dx.doi.org/10.1007/s13280-015-0655-7
Borgström, S. T., T. Elmqvist, P. Angelstam, and C. AlfsenNorodom. 2006. Scale mismatches in management of urban landscapes. Ecology and Society 11(2):16. [online] URL: http:// www.ecologyandsociety.org/vol11/iss2/art16/

Brink, E., T. Aalders, D. Ádám, R. Feller, Y. Henselek, A. Hoffmann, K. Ibe, A. Matthey-Doret, M. Meyer, N. L. Negrut, A.-L. Rau, B. Riewerts, S. Törnros, L. von Schuckmann, H. Von Wehrden, D. J. Abson, and C. Wamsler. 2016. Cascades of green: a review of ecosystem-based adaptation in urban areas. Global Environmental Change 36:111-123. http://dx.doi.org/10.1016/j. gloenvcha.2015.11.003

Bulkeley, H. 2013. Cities and climate change. Routledge, Abingdon, UK.

Bulkeley, H., and M. M. Betsill. 2003. Cities and climate change: urban sustainability and global environmental governance. Routledge, Abingdon, UK. http://dx.doi.org/10.4324/9780203219256

Chong, J. 2014. Ecosystem-based approaches to climate change adaptation: progress and challenges. International Environmental Agreements: Politics, Law and Economics 14:391-405. http://dx. doi.org/10.1007/s10784-014-9242-9

Colding, J., J. Lundberg, and C. Folke. 2006. Incorporating greenarea user groups in urban ecosystem management. Ambio 35 (5):237-244. http://dx.doi.org/10.1579/05-a-098r.1

Colls, A., N. Ash, and N. Ikkala. 2009. Ecosystem-based adaptation: a natural response to climate change. International Union for Conservation of Nature, Gland, Switzerland.

Convention on Biological Diversity (CBD). 2009. Connecting biodiversity and climate change mitigation and adaptation: report of the Second Ad Hoc Technical Expert Group on Biodiversity and Climate Change. Technical Series No. 41. CBD, Montreal, Quebec, Canada.

Daily, G. C., editor. 1997. Nature's services-societal dependence on natural ecosystems. Island Press, Washington, D.C., USA.

Davies C., R. Hansen, E. Rall, S. Pauleit, R. Lafortezza, Y. De Bellis, A. Santos and I. Tosics. 2015. The status of European green space planning and implementation based on an analysis of selected European city-regions. EU FP7 project GREEN SURGE, Deliverable D5.1. European Union, Brussels, Belgium.

Davoudi, S. 2009. Framing the role of spatial planning in climate change. Electronic Working Paper No. 43. Global Urban Research Unit, Newcastle, UK.

Davoudi, S., J. Crawford, and A. Mehmood. 2009. Planning for climate change - strategies for mitigation and adaptation for spatial planners. Earthscan, London, UK.

Dickinson, J. L., J. Shirk, D. Bonter, R. Bonney, R. L. Crain, J. Martin, T. Phillips, and K. Purcell. 2012. The current state of citizen science as a tool for ecological research and public engagement. Frontiers in Ecology and the Environment 10 (6):291-297. http://dx.doi.org/10.1890/110236

Dixon, J. M., K. J. Donati, L. L. Pike, and L. Hattersley. 2009. Functional foods and urban agriculture: two responses to climate change-related food insecurity. New South Wales Public Health Bulletin 20(1-2):14-18. http://dx.doi.org/10.1071/nb08044 
Doswald, N., and M. Estrella. 2015. Promoting ecosystems for disaster risk reduction and climate change adaptation: opportunities for integration. Discussion paper. Partnership for Environment and Disaster Risk Reduction (PEDRR). Post-Conflict and Disaster Management Branch, United Nations Environmental Programme (UNEP), Nairobi, Kenya.

Doswald, N., R. Munroe, D. Roe, A. Giuliani, I. Castellia, J. Stephens, I. Möller, T. Spencer, B. Vira, and H. Reid. 2014. Effectiveness of ecosystem-based approaches for adaptation: review of the evidence-base. Climate and Development 6 (2):185-201. http://dx.doi.org/10.1080/17565529.2013.867247

Doswald, N., and M. Osti. 2011. Ecosystem-based approaches to adaptation and mitigation-good practice examples and lessons learned in Europe. BfN-Skripten 306. German Federal Agency for Nature Conservation (BfN), Bonn, Germany.

Dual Citizen. 2014. The global green economy index (GGEI) 2014. Fourth edition. Dual Citizen, Washington, D.C., USA.

Elmqvist, T., J. Colding, S. Barthel, S. Borgström, A. Duit, J. Lundberg, E. Andersson, K. Ahrné, H. Ernstson, C. Folke, and J. Bengtsson. 2004. The dynamics of social-ecological systems in urban landscapes: Stockholm and the National Urban Park, Sweden. Annals of the New York Academy of Sciences 1023:308-322. http://dx.doi.org/10.1196/annals.1319.017

Elmqvist, T., C. Folke, M. Nyström, G. Peterson, J. Bengtsson, B. Walker, and J. Norberg. 2003. Response diversity, ecosystem change, and resilience. Frontiers in Ecology and the Environment 1(9):488-494. http://dx.doi.org/10.1890/1540-9295(2003)001[0488: rdecar]2.0.co;2

Ernstson, H., S. Sörlin, and T. Elmqvist. 2008. Social movements and ecosystem services - the role of social network structure in protecting and managing urban green areas in Stockholm. Ecology and Society 13(2):39. [online] URL: http://www. ecologyandsociety.org/vol13/iss2/art39/

European Union (EU). 2007. Directive 2007/60/EC of the European Parliament and of the Council of 23 October 2007 on the assessment and management of flood risks. Official Journal of the European Union. L 228/27.

European Union (EU). 2009. The economics of climate change adaptation in EU coastal areas. Country overview and assessment -Sweden. Policy Research Corporation in association with MRAG, Antwerp, Belgium.

European Union (EU). 2013. Strategy on adaptation to climate change. European Commission, Brussels, Belgium.

European Commission (EC). 2015. Towards an EU research and innovation policy agenda for nature-based solutions \& re-naturing cities. Final Report of the Horizon 2020 Expert Group. 35. Directorate-General for Research and Innovation, European Commission, Brussels, Belgium.

Foster, J., A. Lowe, and S. Winkelman. 2011. The value of green infrastructure for urban climate adaptation. Center for Clean Air Policy, Washington, D.C., USA.

Frantzeskaki, N., and N. Tilie. 2014. The dynamics of urban ecosystem governance in Rotterdam, The Netherlands. Ambio 43 (4):542-555. http://dx.doi.org/10.1007/s13280-014-0512-0
Füssel, H.-M. 2007. Adaptation planning for climate change: concepts, assessment approaches, and key lessons. Sustainability Science 2(2):265-275. http://dx.doi.org/10.1007/s11625-007-0032y

Gaffin, S. R., C. Rosenzweig, and A. Y. Y. Kong. 2012. Adapting to climate change through urban green infrastructure. Nature Climate Change 2(10):704-704. http://dx.doi.org/10.1038/ nclimate1685

Gill, S. E., J. F. Handley, A. R. Ennos, and S. Pauleit. 2007. Adapting cities for climate change: the role of the green infrastructure. Built Environment 33(1). http://dx.doi.org/10.2148/ benv.33.1.115

Glaser, B. G., and A. L. Strauss. 1967. The discovery of grounded theory: strategies for qualitative research. Aldine de Gruyter, New York, New York, USA.

Glaser, B. G., and A. L. Strauss. 1980. Time for dying. First published in 1968. Aldine de Gruyter, New York, New York, USA.

Granberg, M., and I. Elander. 2007. Local governance and climate change: reflections on the Swedish experience. Local Environment: International Journal of Justice and Sustainability 12(5):537-548. http://dx.doi.org/10.1080/13549830701656911

Gupta, A. K., and S. S. Nair. 2012. Ecosystem approach to disaster risk reduction. National Institute of Disaster Management, New Delhi, India.

Haines-Young, R., and M. Potschin. 2013. Common international classification of ecosystem services (CICES): consultation on version 4, August-December 2012. EEA Framework Contract No EEA/IEA/09/003. Centre for Environmental Management, University of Nottingham, Nottingham, UK.

Hansen R., M. Buizer, E. Rall, Y. De Bellis, C. Davies, B. Elands, W. Freerk and S. Pauleit. 2015. Report of case study city portraits. Appendix to GREEN SURGE study on urban green infrastructure planning and governance in 20 European case studies. Technical report. European Union, Brussels, Belgium.

Healey, P. 1997. Collaborative planning: shaping places in fragmented societies. University of British Columbia Press, Vancouver, British Columbia, Canada. http://dx.doi. org/10.1007/978-1-349-25538-2

Helsingborgs stad. 2012. PM Klimatanpassning: fördjupningspromemoria om Helsingborgs stads klimatanpassning. Helsingborgs stad, Skane, Sweden.

Hertin, J., and F. Berkhout. 2001. Ecological modernisation and EU environmental policy integration. SPRU Electronic Working Paper Series No. 72. University of Sussex, Brighton, UK.

Holden, S. 2004. Mainstreaming HIVIAIDS in development and humanitarian programmes. Oxfam, Oxford, UK. http://dx.doi. org/10.3362/9780855987909

Hördur, H.V. 2004. Introduction to system thinking and causal loop diagrams. Reports on Ecology and Environmental Engineering 2004(1), Institute of Chemical Engineering, Lund University, Lund, Sweden. 
Hubacek, K., and J. Kronenberg. 2013. Synthesizing different perspectives on the value of urban ecosystem services. Landscape and Urban Planning 109(1):1-6. http://dx.doi.org/10.1016/j. landurbplan.2012.10.010

Hougner, C., J. Colding, and T. Söderqvist. 2005. Economic valuation of a seed dispersal service in the Stockholm National Urban Park, Sweden. Beijer International Institute of Ecological Economics, Stockholm, Sweden.

Huq, N., F. Renaud, and Z. Sebesvari. 2013. Ecosystem based adaptation ( $E B A)$ to climate change-integrating actions to sustainable adaptation. United Nations University, Institute for Environment and Human Security (UNU-EHS), Bonn, Germany.

Intergovernmental Panel on Climate Change (IPCC). 2007. Climate change 2007: impacts, adaptation and vulnerability. M. L. Parry, O. F. Canziani, J. P. Palutikof, P. J. van der Linden, and C. E. Hanson, editors. Working Group II contribution to the Fourth Assessment Report of the Intergovernmental Panel on Climate Change. Cambridge University Press, Cambridge, UK.

Intergovernmental Panel on Climate Change (IPCC). 2012. Managing the risks of extreme events and disasters to advance climate change adaptation. C. B. Field, V. Barros, T. F. Stocker, and Q. Dahe, editors. A special report of Working Groups I and II of the Intergovernmental Panel on Climate Change. Cambridge University Press, Cambridge, UK.

Intergovernmental Panel on Climate Change (IPCC). 2014. Climate change 2014: impacts, adaptation, and vulnerability. C. B. Field, V. R. Barros, D. J. Dokken, K. J. Mach, M. D. Mastrandrea, T. E. Bilir, M. Chatterjee, K. L. Ebi, Y. O. Estrada, R. C. Genova, B. Girma, E. S. Kissel, A. N. Levy, S. MacCracken, P. R. Mastrandrea, and L. L. White, editors. Working Group II contribution to the Fifth Assessment Report of the Intergovernmental Panel on Climate Change. Cambridge University Press, Cambridge, UK.

Jansson, Å., and J. Colding. 2007. Tradeoffs between environmental goals and urban development: the case of nitrogen load from the Stockholm County to the Baltic Sea. Ambio 36 (8):650-656. http://dx.doi.org/10.1579/0044-7447(2007)36[650: tbegau]2.0.co;2

Jansson, A., and P. Nohrstedt. 2001. Carbon sinks and human freshwater dependence in Stockholm County. Ecological Economics 39(3):361-370. http://dx.doi.org/10.1016/s0921-8009 (01)00224-5

Jones, H. P., D. G. Hole, and E. S. Zavaleta. 2012. Harnessing nature to help people adapt to climate change. Nature Climate Change 2(7):504-509. http://dx.doi.org/10.1038/nclimate1463

Jordan, A., and A. Lenschow. 2000. 'Greening' the European Union: what can be learned from the 'leaders' of EU environmental policy? European Environment 10(3):109-120. http://dx.doi.org/10.1002/1099-0976(200005/06)10:3<109::AIDEET227>3.0.CO:2-Z

Kithiia, J., and A. Lyth. 2011. Urban wildscapes and green spaces in Mombasa and their potential contribution to climate change adaptation and mitigation. Environment \& Urbanization 23 (1):251-265. http://dx.doi.org/10.1177/0956247810396054
Kremen, C. 2005. Managing ecosystem services: what do we need to know about their ecology? Ecology Letters 8(5):468-479. http:// dx.doi.org/10.1111/j.1461-0248.2005.00751.x

Kristianstads kommun. 2009. Klimatanpassning program 2009-2012. Ett deldokument $i$ Klimatstrategi för Kristianstads kommun. Kristianstads kommun, Kristianstad, Sweden.

Kristianstads kommun. 2011. Klimatstrategi och energiplan samt strategi för Energi- effektiviserings-stödet. Mål och handlingsplan. Kristianstads kommun, Kristianstad, Sweden.

Länsstyrelsen i Skåne län. 2014. Biologisk mångfald i de skånska kommunernas planeringsunderlag och verksamheter. Länsstyrelsen i Skåne län, Malmö, Sweden.

Länsstyrelsen Skåne. 2014. Regional handlingsplan för klimatanpassning för Skåne 2014-Insatser för att förstärka Skånes väg mot ett robust samhälle. Report number 2014:7. Länsstyrelsen Skåne, Malmö, Sweden.

Länsstyrelserna. 2012. Klimatanpassning $i$ fysisk planeringVägledning från länsstyrelserna. Länsstyrelserna, Malmö, Sweden.

Larondelle, N., D. Haase, and N. Kabisch. 2014. Mapping the diversity of regulating ecosystem services in European cities. Global Environmental Change 26:119-129. http://dx.doi. org/10.1016/j.gloenvcha.2014.04.008

Lavorel, S., M. J. Colloff, S. McIntyre, M. D. Doherty, H. T. Murphy, D. J. Metcalfe, M. Dunlop, R. J. Williams, R. M. Wise, and K. J. Williams. 2015. Ecological mechanisms underpinning climate adaptation services. Global Change Biology 21:12-31. http://dx.doi.org/10.1111/gcb.12689

Layder, D. 2005. Sociological practice: linking theory and social research. First published in 1998. Sage, London, UK.

Lenschow, A, editor. 2002. Environmental policy integration: greening sectoral policies in Europe. Earthscan, Abingdon, UK.

Liu, J., G. C. Daily, P. R. Ehrlich, and G. W. Luck. 2003. Effects of household dynamics on resource consumption and biodiversity. Nature 421(6922):530-533. http://dx.doi.org/10.1038/ nature 01359

Luck, G. W., R. Harrington, P. A. Harrison, C. Kremen, P. M. Berry, R. Bugter, T. R. Dawson, F. de Bello, S. Díaz, C. K. Feld, J. R. Haslett, D. Hering, A. Kontogianni, S. Lavorel, M. Rounsevell, M. J. Samways, L. Sandin, J. Settele, M. T. Sykes, S. van den Hove, M. Vandewalle, and M. Zobel. 2009. Quantifying the contribution of organisms to the provision of ecosystem services. BioScience 59(3):223-235. http://dx.doi.org/10.1525/ bio.2009.59.3.7

Millennium Ecosystem Assessment. 2005. Ecosystems and human well-being: current state and trends. Island Press, Washington, D. C., USA.

Malmö stad. 2008. Klimatet, havsnivån och planeringen: Dialog$P M$. Malmö stad, Malmö, Sweden.

Malmö stad. 2011. Climate adaptation strategy. Malmö stad, Malmö, Sweden.

Malmö stad. 2012. Handlingsplan för klimatanpassning Malmö 2012-2014. Malmö stad, Malmö, Sweden. 
Ministry of the Environment. 2013. Making the value of ecosystem services visible: Proposals to enhance well-being through biodiversity and ecosystem services. Ministry of the Environment, Stockholm, Sweden.

Moser, S. C., and J. A. Ekstrom. 2010. A framework to diagnose barriers to climate change adaptation. Proceedings of the National Academy of Sciences of the United States of America 107 (51):22026-22031. http://dx.doi.org/10.1073/pnas.1007887107

Munang, R., J. Andrews, K. Alverson, and D. Mebratu. 2013. Harnessing ecosystem-based adaptation to address the social dimensions of climate change. Environment: Science and Policy for Sustainable Development 56(1):18-24. http://dx.doi. org/10.1080/00139157.2014.861676

Nadin, V., and D. Stead. 2008. European spatial planning systems, social models and learning. dis P-The Planning Review 44 (172):35-47. http://dx.doi.org/10.1080/02513625.2008.10557001

Nakagawa, Y., and R. Shaw. 2004. Social capital: a missing link to disaster recovery. International Journal of Mass Emergencies and Disasters 22(1):5-34.

Naumann, S., G. Anzaldua, P. Berry, S. Burch, M. Davis, A. Frelih-Larsen, H. Gerdes, and M. Sanders. 2011. Assessment of the potential of ecosystem-based approaches to climate change adaptation and mitigation in Europe. Final report to the European Commission, DG Environment. Contract no. 070307/2010/580412/ SER/B2. Ecologic Institute and Environmental Change Institute, Oxford University Centre for the Environment, Oxford, UK.

Niemelä, J., S.-R. Saarela, T. Söderman, L. Kopperoinen, V. YliPelkonen, S. Väre, and D. J. Kotze. 2010. Using the ecosystem services approach for better planning and conservation of urban green spaces: a Finland case study. Biodiversity and Conservation 19(11):3225-3243. http://dx.doi.org/10.1007/s10531-010-9888-8

Pelling, M. 1998. Participation, social capital and vulnerability to urban flooding in Guyana. Journal of International Development 10(4):469-486. http://dx.doi.org/10.1002/(sici)1099-1328 (199806)10:4<469::aid-jid539>3.0.c0;2-4

Persson, A., K. Eckerberg, and M. Nilsson. 2015. Institutionalization or wither away: 25 years of environmental policy integration in Swedish energy and agricultural policy. Environment and Planning C: Government and Policy Nov 16:0263774X15614726.

Queiroz, C., M. Meacham, K. Richter, A. V. Norström, E. Andersson, J. Norberg, and G. Peterson. 2015. Mapping bundles of ecosystem services reveals distinct types of multifunctionality within a Swedish landscape. Ambio 44(1):89-101. http://dx.doi. org/10.1007/s13280-014-0601-0

Rauken, T., P. K. Mydske, and M. Winsvold. 2015. Mainstreaming climate change adaptation at the local level. Local Environment: International Journal of Justice and Sustainability 20(4):408-423. http://dx.doi.org/10.1080/13549839.2014.880412

Reimer, M., P. Getimis, and H. Heinrich Blotevogel. 2014. Spatial planning systems and practices in Europe: a comparative perspective on continuity and changes. Routledge, London, UK.

Roberts, D. 2008. Thinking globally, acting locallyinstitutionalizing climate change at the local government level in
Durban, South Africa. Environment \& Urbanization 20 (2):521-537. http://dx.doi.org/10.1177/0956247808096126

Roberts, D. 2010. Prioritizing climate change adaptation and local level resilience in Durban, South Africa. Environment \& Urbanization 22(2):397-413. http://dx.doi.org/10.1177/0956247810379948

Roberts, D., R. Boon, N. Diederichs, E. Douwes, N. Govender, A. Mcinnes, C. Mclean, S. O'Donoghue, and M. Spires. 2011. Exploring ecosystem-based adaptation in Durban, South Africa: "learning-by-doing" at the local government coal face. Environment \& Urbanization 24(1):167-195. http://dx.doi. org/10.1177/0956247811431412

Schewenius, M., T. McPhearson, and T. Elmqvist. 2014. Opportunities for increasing resilience and sustainability of urban social-ecological systems: insights from the URBES and the Cities and Biodiversity Outlook projects. Ambio 43:434-444. http://dx. doi.org/10.1007/s13280-014-0505-Z

Sitas, N., H. E. Prozesky, K. J. Esler, and B. Reyers. 2014. Exploring the gap between ecosystem service research and management in development planning. Sustainability 6:3802-3824. http://dx.doi.org/10.3390/su6063802

Sovacool, B. K. 2011. Hard and soft paths for climate change adaptation. Climate Policy 11(4):1177-1183. http://dx.doi. org/10.1080/14693062.2011.579315

Statens Offentliga Utredningar (SOU). 2007. Sweden facing climate change - threats and opportunities. Final report from the Swedish commission on Climate and Vulnerabilility. Swedish Government Official Reports, Stockholm, Sweden.

Statens Offentliga Utredningar (SOU). 2013. Synliggöra värdet av ekosystemtjänster-Åtgärder för välfärd genom biologisk mångfald och ekosystemtjänster. Swedish Government Official Reports, Stockholm, Sweden.

Statens Offentliga Utredningar (SOU). 2014. Med miljömålen $i$ fokus-hållbar användning av mark och vatten. Swedish Government Official Reports, Stockholm, Sweden.

Storbjörk, S. 2007. Governing climate adaptation in the local arena: challenges of risk management and planning in Sweden. Local Environment: International Journal of Justice and Sustainability 12(5):457-469. http://dx.doi.org/10.1080/1354983$\underline{0701656960}$

Stott, C., and S. Huq. 2014. Knowledge flows in climate change adaptation: exploring friction between scales. Climate and Development 6(4):382-387. http://dx.doi.org/10.1080/17565529.2014.951014

Strauss, A. L., and J. Corbin. 1998. Basics of qualitative research. Techniques and procedures for developing grounded theory. Second edition. Sage, Thousand Oaks, California, USA.

Sveriges Meteorologiska och Hydrologiska Institut (SMHI). 2011. Klimatanalys för Skåne län. SMHI, Norrköping, Sweden.

Swedish Association of Local Authorities and Regions (SALAR) [date unknown]. Levels of local democracy in Sweden. SALAR, Stockholm, Sweden.

Thomalla, F., T. Downing, E. Spanger-Siegfried, G. Han, and J. Rockström. 2006. Reducing hazard vulnerability: towards a 
common approach between disaster risk reduction and climate adaptation. Disasters 30(1):39-48. http://dx.doi.org/10.1111/ j.1467-9523.2006.00305.x

Tompkins, E. L., W. N. Adger, E. Boyd, S. Nicholson-Cole, K. Weatherhead, and N. Arnell. 2010. Observed adaptation to climate change: UK evidence of transition to a well-adapting society. Global Environmental Change 20(4):627-635. http://dx. doi.org/10.1016/j.gloenvcha.2010.05.001

Tongco, M. D. C. 2007. Purposive sampling as a tool for informant selection. Ethnobotany Research and Applications 5:147-158.

Turnpenny J., D. Russel, and A. Jordan. 2014. The challenge of embedding an ecosystem services approach: patterns of knowledge utilisation in public policy appraisal. Environment and Planning C: Government and Policy 32(2):247-262. http://dx.doi. org/10.1068/c1317j

Uittenbroek, C. J., L. B. Janssen-Jansen, and H. A. C. Runhaar. 2013. Mainstreaming climate adaptation into urban planning: overcoming barriers, seizing opportunities and evaluating the results in two Dutch case studies. Regional Environmental Change 13:399-411. http://dx.doi.org/10.1007/s10113-012-0348-8

United Nations Environment Programme (UNEP). 2011. Restoring the natural foundation to sustain a Green Economy: a century-long journey for ecosystem management. International Ecosystem Management Partnership (IEMP). UNEP Policy Series 6. UNEP, Nairobi, Kenya

United Nations Framework Convention on Climate Change (UNFCCC). 2011. Ecosystem-based approaches to adaptation: compilation of information. FCCC/SBSTA/2011/INF.8. UNFCCC, Bonn, Germany. [online] URL: http://unfecc.int/resource/ docs/2011/sbsta/eng/inf08.pdf

United Nations Framework Convention on Climate Change (UNFCCC). 2012. Slow onset events. Technical paper. FCCC/ TP/2012/7. UNFCCC, Bonn, Germany. [online] URL: http:// unfccc.int/resource/docs/2012/tp/07.pdf

United Nations Office for Disaster Risk Reduction (UNISDR). 2005. Hyogo framework for action: building the resilience of nations and communities to disasters. A/CONF.206/6. UNISDR, Geneva, Switzerland.

United Nations Office for Disaster Risk Reduction (UNISDR). 2015. Sendai framework for disaster risk reduction 2015-2030. A/ CONF.224/CRP.1. UNISDR, Geneva, Switzerland.

Uy, N., and R. Shaw. 2012. Overview of ecosystem-based adaptation. Pages 3-17 in N. Uy and R. Shaw, editors. Community, environment and disaster risk management. Volume 12. Emerald Group, Bingley, UK. http://dx.doi.org/10.1108/s2040-7262(2012) $\underline{0000012007}$

Uy, N., Y. Takeuchi, and R. Shaw. 2012. An ecosystem-based resilience analysis of Infanta, Philippines. Environmental Hazards 11(4):266-282. http://dx.doi.org/10.1080/17477891.2012.688794

Vignola, R., B. Locatelli, C. Martinez, and P. Imbach. 2009. Ecosystem-based adaptation to climate change: what role for policy-makers, society and scientists? Mitigation and Adaptation Strategies for Global Change 14(8):691-696. http://dx.doi. org/10.1007/s11027-009-9193-6 von Bertalanffy, L. 1950. An outline of general systems theory. British Journal for the Philosophy of Science 1:134-165. http://dx. doi.org/10.1093/bjps/I.2.134

Wamsler, C. 2007. Managing urban disaster risk: analysis and adaptation frameworks for integrated settlement development programming for the urban poor. Dissertation. Lund University, Lund, Sweden.

Wamsler, C. 2014. Cities, disaster risk and adaptation. Routledge, London, UK.

Wamsler, C. 2015. Mainstreaming ecosystem-based adaptation: transformation toward sustainability in urban governance and planning. Ecology and Society 20(2):30. http://dx.doi. org/10.5751/ES-07489-200230

Wamsler, C., E. Brink, and C. Rivera. 2013. Planning for climate change in urban areas: from theory to practice. Journal of Cleaner Production 50:68-81. http://dx.doi.org/10.1016/j.jclepro.2012.12.008

Wamsler, C., C. Luederitz, and E. Brink. 2014. Local levers for change: mainstreaming ecosystem-based adaptation into municipal planning to foster sustainability transitions. Global Environmental Change 29:189-201. http://dx.doi.org/10.1016/j. gloenvcha.2014.09.008

Wilkinson, C., T. Saarne, G. D. Peterson, and J. Colding. 2013. Strategic spatial planning and the ecosystem services conceptan historical exploration. Ecology and Society 18(1):37. http://dx. doi.org/10.5751/ES-05368-180137

World Bank. 2009. Convenient solutions to an inconvenient truth: ecosystem-based approaches to climate change. Environment Department, World Bank, Washington, D.C., USA. http://dx. doi.org/10.1596/978-0-8213-8126-7

Wu, J. 2014. Urban ecology and sustainability: the state-of-thescience and future directions. Landscape and Urban Planning 125:209-221. http://dx.doi.org/10.1016/j.landurbplan.2014.01.018

Yin, R. K. 2009. Case study research: design and methods. Fourth edition. Sage, Thousand Oaks, California, USA. 